\title{
Analgesic-Like Activity of Essential Oil Constituents: An Update
}

\author{
Rita de Cássia da Silveira e Sá ${ }^{1}$, Tamires Cardoso Lima ${ }^{2}$, Flávio Rogério da Nóbrega ${ }^{3}$, \\ Anna Emmanuela Medeiros de Brito ${ }^{3}$ and Damião Pergentino de Sousa ${ }^{3, *}$ \\ 1 Departamento de Fisiologia e Patologia, Universidade Federal da Paraíba, CP 5009, \\ João Pessoa-PB 58051-970, Brazil; ritacassia.sa@bol.com.br \\ 2 Departamento de Farmácia, Universidade Federal de Sergipe, São Cristóvão-SE 49100-000, Brazil; \\ tamires.cl87@gmail.com \\ 3 Departamento de Ciências Farmacêuticas, Universidade Federal da Paraíba, João Pessoa-PB 58051-970, \\ Brazil; frnobrega@hotmail.com (F.R.N.); manubbrito@hotmail.com (A.E.M.B.) \\ * Correspondence: damiao_desousa@yahoo.com.br; Tel.: +51-83-3209-8417
}

Received: 23 October 2017; Accepted: 3 November 2017; Published: 9 December 2017

\begin{abstract}
The constituents of essential oils are widely found in foods and aromatic plants giving characteristic odor and flavor. However, pharmacological studies evidence its therapeutic potential for the treatment of several diseases and promising use as compounds with analgesic-like action. Considering that pain affects a significant part of the world population and the need for the development of new analgesics, this review reports on the current studies of essential oils' chemical constituents with analgesic-like activity, including a description of their mechanisms of action and chemical aspects.
\end{abstract}

Keywords: analgesic; antinociceptive; terpenes; phenylpropanoid; natural products; medicinal plants; aromas; flavor; volatile; food

\section{Introduction}

Constituents of essential oils are commonly found in foods giving characteristic aroma and flavor. Several plants and their fruits can be recognized by the aroma provided by volatile substances, which are generally alcohols, aldehyde ketones, esters, hydrocarbons, phenols, among other chemical classes. For example, alcohol linalool can be found in mango, papaya and pineapple fruit. While the hydrocarbon limonene is present in orange, lemon and guava [1]. In cooking, the aroma of spices is due to the presence of these volatile compounds, such as phenol eugenol found in clove (Syzygium aromaticum (L.) Merrill \& Perry) [2]. Therefore, people are always in contact with these constituents through food.

Essential oils are a class of natural products with promising biological properties and are traditionally used in aromatherapy for various purposes. Pharmacological and clinical studies have demonstrated the profile of these compounds as drug candidates [3]. For example, the monoterpene perillyl alcohol has preventive and therapeutic effects in a wide variety of preclinical tumor models and is currently under phase I and phase II clinical trials, including against glioblastomas multiforme. Elemene and D-limonene are essential oil constituents also tested in patients with cancer [3]. In fact, several reviews have suggested the therapeutic potential of this group into multiple areas, including analgesics, whose activity presents a large number of published studies $[4,5]$, anticonvulsants [6], anti-inflammatories [7-9], anticancer agents [10,11], anxiolytics [12], and antiulcer agents [13]. Studies of the anxiolytic effects have scientifically proven the therapeutic use of several essential oils in aromatherapy. The inhalation route is an interesting route for several therapeutic approaches using these natural products $[3,12]$. The chemical diversity found in essential oils may be 
responsible for these variety of pharmacological activities and possibly the various mechanisms of action of their chemical constituents. These findings not only support the traditional use of aromatic plants and their essential oils but also highlight analgesic-like uses of these natural products. In addition, antitumor essential oils with pharmacological activity in animal models of pain may have a dual effect on the therapeutic approach of patients with cancer. Pain is defined as an unpleasant sensory and emotional experience associated with actual or potential tissue damage, or described in terms of such damage [14]. This symptom affects a lot of people in the world, mainly patients with some types of chronic pathologies, causing loss of good quality of life. In response to the demand for powerful analgesics and with less side effects many studies have been conducted to discover bioactive substances with profiles of analgesic drug candidates. Therefore, with the aim of contributing to the report of natural compounds with antinociceptive activity, the purpose of this review was to conduct a systematic investigation of studies on the essential oil constituents in experimental models related to antinociceptive activity. This article is an update of our latest review on the topic [4] and describes new studies conducted over the past six years.

\section{Results}

\section{1. $p$-Cymene}

The aromatic monocyclic monoterepene $p$-cymene [1-methyl-4-(1-methylethyl) benzene] is the biological precursor of carvacrol and is abundantly found in essential oils from many plant species such as Protium heptaphyllum (Aubl.) Marchand (Burseraceae) [15] and Hyptis pectinata (L.) Poit. (Lamiaceae) [16]. It also occurs naturally in a wide variety of foods, including orange juice, carrots, tangerine, butter and oregano [17]. The antinociceptive and anti-inflammatory activities of $p$-cymene have been evaluated by different behavioral tests of nociception in rodents, which showed that this monoterpene exerted both peripheral and central antinociceptive action. For instance, the antinociceptive effect of $p$-cymene was demonstrated on an orofacial nociceptive response model through tests involving the subcutaneous administration of formalin, capsaicin, and glutamate into the upper lip of $p$-cymene-pretreated male Swiss mice (25, 50 or $100 \mathrm{mg} / \mathrm{kg}$, i.p.). p-Cymene markedly decreased the rubbing behavior induced by all three components; an effect counteracted by nonselective opioid receptor antagonist naloxone, indicating the participation of the opioid system in the antinociceptive response [18].

A study developed by Bonjardim and collaborators [19] revealed that, in the acetic acid-induced writhing and formalin tests, exposure of male Swiss mice to $p$-cymene (50 or $100 \mathrm{mg} / \mathrm{kg}$, i.p.) significantly decreased the number of writhes and the licking time in the first and second phase of the formalin test. In the hot plate test, it increased the latency time of the licking and jumping behavior to thermal stimulus. Additionally, $p$-cymene $(25,50$ or $100 \mathrm{mg} / \mathrm{kg}$ ) produced an anti-inflammatory reaction induced by carrageenan (CG), which led to a marked reduction in leukocyte migration. In mice, intraplantar injection of CG leads to hypernociception and an inflammatory response that involves the release of cytokines by resident or migrating cells initiated by the production of bradykinin [20]. This is followed by the secretion of prostanoids and sympathomimetic amines, such as dopamine [21], which stimulate $\mathrm{A} \delta$ and $\mathrm{C}$ fiber nerve terminals and the release of substance $\mathrm{P}$ and neurokinin $\mathrm{A}$, accentuating local blood flow and vascular permeability [22]. In CG-induced hypernociception, the release of tumor necrosis fator $\alpha$ (TNF- $\alpha$ ) and keratinocyte-derived chemokine (KC), for exemple, is accompanied by the secretion of interleukin $1 \beta$ (IL-1 $\beta$ ) [23] with the subsequent induction of cyclooxigenase-2 (COX-2) expression and the production of protanoids, such as prostagladin E2 (PGE2) [24].

Other studies have provided further evidence of the antinociceptive and anti-inflammatory properties of $p$-cymene and the possible role of the opioid system and cytokines in these responses. The antinociceptive effect of $p$-cymene $(25-100 \mathrm{mg} / \mathrm{kg})$ on male Swiss mice was demonstrated in the tail flick test, showing increased dose-dependent reaction time, an effect that lasted for five hours and was antagonized by naloxone and by $\delta, \kappa$ and $\mu$-opioid receptor antagonists 
naltrindole, nor-binaltorphimine (Nor-BNI) and CTOP (D-Phe-Cys-Tyr-D-Trp-Orn-Thr-Pen-Thr amide), respectively [25]. In the assessment of the anti-inflammatory activity, treatment with $p$-cymene $(25,50$ or $100 \mathrm{mg} / \mathrm{kg}$, i.p.) decreased mechanical hyperalgesia induced by CG, TNF- $\alpha$, PGE2, and dopamine. In the CG-induced pleurisy test, $p$-cymene reduced leukocyte $(100 \mathrm{mg} / \mathrm{kg})$ and neutrophils (50 and $100 \mathrm{mg} / \mathrm{kg}$ ) migration to the pleural cavity, and decreased the levels of TNF- $\alpha$ in pleural exudates (25, 50 and $100 \mathrm{mg} / \mathrm{kg}$ ). Neutrophils, in particular, play an important role at the onset of inflammatory hypernociception by secreting pro-inflammatory cytokines (e.g., TNF- $\alpha$ and IL-1 $\beta$ ) and mediators such as prostaglandins $[26,27]$. $p$-Cymene was also shown to diminish nitric oxide (NO) production in murine macrohages incubated with lipopolysaccharide (LPS) $(25,50$ and $100 \mu \mathrm{g} / \mathrm{mL})$, a component known to stimulate toll-like receptor 4 (TLR-4), leading to the activation of the transcription factor NF- $\kappa B$ [25]. NF- $\mathrm{B}$ contributes to the production of inflammatory (pro-nociceptive) molecules and enhances inducible nitric oxide synthase (iNOS) activity, thereby increasing NO production [28], which is believed to act as a mediator of inflammation and to sustain hyperalgesia after CG injection [29]. Furthermore, $p$-cymene significantly enhanced the c-Fos immunoreactive neurons in the periaqueductal gray [25], a midbrain region activated by opioid agonists and involved with pain modulation [30]. Together these findings indicate an anti-inflammatory and antinociceptive action of $p$-cymene and suggest the involvement of descending pain suppression mechanisms since its antinociceptive role through the opioid system was increased by the activation of the periaqueductal gray [25].

The assessment of the antinociceptive property and redox profile of $p$-cymene and two other monoterpenes, namely (+)-camphene and geranyl acetate, revealed that $p$-cymene possessed the strongest antinociceptive action (50, 100 and $200 \mathrm{mg} / \mathrm{kg}$, i.p.) while (+)-camphene and geranyl acetate $(200 \mathrm{mg} / \mathrm{kg})$ displayed a moderate analgesic effect in male Swiss mice tested in the acetic acid-induced writhing and formalin models [31]. In contrast, (+)-camphene exhibited the most relevant antioxidant effect in vitro detected by two specific assays: the thiobarbituric acid-reactive species (TBARS) — an assay employed to quantify lipid peroxidation [32] - and the total reactive antioxidant potential (TRAP)/total antioxidante reactivity (TAR) — an assay employed to estimate the nonenzymatic antioxidant capacity of samples [33]. It also showed the highest scavenging activity against different free radicals, including hydroxyl and superoxide radicals [31].

\subsection{Carvacrol}

Carvacrol (5-isopropyl-2-methylphenol) is a phenolic monoterpene found in essential oils of plants from the genera Origanum and Thymus (Lamiaceae) [34,35]. Its phamacological properties include acetylcholinesterase inhibition [36], and anticonvulsive [37], anxiolytic [38], and antinociceptive [39] action. The antinociceptive activity of carvacrol was demonstrated in male Swiss mice tested in animal models of pain (acetic acid-induced writhing, formalin and hot plate). The data obtained after oral treatment with single doses of carvacrol showed a decrease in the number of constrictions (50, 100 and $200 \mathrm{mg} / \mathrm{kg}$ ), and the paw-licking time ( $50 \mathrm{mg} / \mathrm{kg}$, first phase of the formalin test; $100 \mathrm{mg} / \mathrm{kg}$, first and second phases), and an increase in the reaction time at $60 \mathrm{~min}(50 \mathrm{and} 100 \mathrm{mg} / \mathrm{kg}$ ) in the hot plate test. These effects were not reversed by naloxone and L-arginine, suggesting that the antinociceptive action of carvacrol may not be related to the opioid system [40]. On the other hand, the antinociceptive activity of carvacrol was associated with the inhibition of prostaglandin synthesis [39] as it possesses an effective ability to suppress COX-2 expression and to activate the peroxisome proliferator-activated receptors (PPAR) $\alpha$ and $\gamma$ [41].

In a study by Guimarães and collaborators [42], the role of carvacrol in the attenuation of mechanical hypernociception and inflammation was investigated in models of hypernociception induced by CG, TNF- $\alpha$, PGE2 and dopamine, and in models of CG-induced pleurisy, paw edema, and LPS-induced nitrite production in murine macrophages. The administration of carvacrol (50 or $100 \mathrm{mg} / \mathrm{kg}$, i.p.) to male Swiss mice significantly suppressed mechanical hypernociception and paw edema induced by CG and TNF- $\alpha$ (but not PGE2 and dopamine), and markedly reduced TNF- $\alpha$ levels in pleural lavage, blocked leukocytes recruitment, and decreased LPS-induced nitrite 
production in vitro (carvacrol: 1, 10 or $100 \mu \mathrm{g} / \mathrm{mL}$ ). Additionally, Guimarães and collaborators [43] also demonstrated the antinociceptive effect of carvacrol in the formalin-, capsaicin-, and glutamate-induced orofacial nociception tests in which male Swiss mice exhibited reduced face-rubbing behavior in both phases of the formalin test, and nociception induced by capsaicin and glutamate (carvacrol-25, 50 or $100 \mathrm{mg} / \mathrm{kg}$, i.p.).

The antinociceptive action of carvacrol was further corroborated by a study developed by Luo and colloborators [44] in the assessment of its activity on glutamatergic spontaneous excitatory transmission in substantia gelatinosa neurons of the spinal dorsal horn, a region believed to modulate nociceptive transmission from the peripheral to the central nervous system [44,45]. By the use of the patch-clamp method in adult rat spinal cord slices, it was verified that exposure to carvacrol increased the secretion of L-glutamate from nerve terminals by activating transient receptor potential cation channels, subfamily A, member 1 (TRPA1), and produced membrane hyperpolarization; an effect that could be contributing to its anti-inflammatory action. Several studies have recognized TRP as important analgesic targets in inflammatory and neurophatic pains [46]. Another contribution was given by Joca and collaborators [47] that examined possible mechanisms involved in the effects of carvacrol on the peripheral nervous system. Carvacrol reversibly and dose-dependently suppressed the excitability of the rat sciatic nerve ( $\mathrm{IC}_{50}$ value of $\left.0.50 \pm 0.04 \mathrm{mM}\right)$, and prevented the generation of action potentials ( $\mathrm{IC}_{50} 0.36 \pm 0.14 \mathrm{mM}$ ) of the intact dorsal root ganglion (DRG) neurons without altering the resting potential and input resistance. Carvacrol also suppressed neuronal excitability by a direct inhibition of the voltage gated sodium current of dissociated DRG neurons ( $\left.\mathrm{IC}_{50} 0.37 \pm 0.05 \mathrm{mM}\right)$, suggesting a local anesthetic effect of this compound.

\subsection{Linalool}

(-)-Linalool is an enantiomer monoterpene present in essential oils of various aromatic plants, such as lavender, rosewood and bergamot [48], and possesses several pharmacological activities including anti-inflammatory, anxiolytic, anticonvulsant and antinociceptive [49-53]. The effects of (-)-linalool, extracted from the essential oil of Ocimum basilicum L. (Lamiaceae) leaf, on orofacial nociception were addressed in formalin, glutamate and capsaicin tests and in an electrophysiological protocol, which involved the evaluation of the neuronal excitability of the hippocampal dentate gyrus. (-)-Linalool (50, 100 and $200 \mathrm{mg} / \mathrm{kg}$, i.p.) administered to male Swiss mice effectively inhibited the nocifensive face-rubbing behavior in the first and second phase of the formalin test. At high doses, it also reduced nociceptive behavior in neurogenic inflammatory nociception induced by capsaicin and glutamate injection in the perinasal area (right upper lip) [53]. It is believed that these effects are related to possible inhibition of substance $P$ release or blocking effect on its receptor neurokinin-1 (NK-1) [54]. In addition, the electrophysiological analysis revealed that (-)-linalool inhibited the field potentials activated by the antidromic stimulation of the hylus, suggesting that this compound affects the activation of the voltage-dependent sodium channels present in the granular neurons of the hippocampal dentate gyrus [53,55]. Similar results were observed with the O. basilicum leaf essential oil, indicating that both the oil and (-)-linalool display modulatory action on neurogenic and inflammatory pain, and that the antinociceptive effect could be related to reduced peripheral and central nerve excitability [53].

The antinociceptive activity of $( \pm)$-linalool was evidenced in the paclitaxel-induced acute pain model in male ddY-strain mice. Intraplantar injection of $( \pm)$-linalool $(5$ and $10 \mu \mathrm{g} / \mathrm{paw})$ effectively and dose-dependently suppressed behavioral responses of paclitaxel-induced mechanical allodynia and hyperalgesia. $( \pm)$-Linalool injected into the ipsilateral paw produced antiallodynia and antihyperalgesia effects whereas no such action was detected in the linalool-injected contralateral paw, suggesting that the effects exerted by this monoterpene may be mediated locally rather than systemically. Moreover, $( \pm)$-linalool's effects were reversed by local (paw plantar surface) administration of naloxone hydrochloride (opioid antagonist) and by naloxone methiodide 
(peripherally acting opioid receptor antagonist), indicating that $( \pm)$-linalool's peripheral antiallodynia and antihyperalgesia activities could partly involve peripheral opiod mechanisms [48].

Bergamot essential oil extracted from Citrus bergamia (Risso, Rutaceae) is a rich source of linalool. The investigation of their effects on neurophatic hypersensitivity induced by partial sciatic nerve ligation (PSNL) in male ddY-strain mice showed that intraplantar injection of these components into the ipsilateral hindpaw decreased PSNL-induced mechanical allodynia dose-dependently whereas no antinociceptive activity was observed after intraplantar injection into the contralateral hindpaw, further suggesting a local effect of linalool and also of bergamot essential oil [56]. The possible involvement of spinal extracellular signal-regulated protein kinase (ERK) in bergamot essential oil and linalool-induced antimechanical nociception indicates that the attenuation of the observed effects entailed inhibition of spinal ERK phosphorylation since intraplantar injection of bergamot essential oil or linalool effectively blocked spinal ERK activation induced by PSNL [56]. The activation of ERK has been demonstrated in dorsal horn neurons in persistent CG and Freund's adjuvant-induced inflammatory hyperalgesia $[57,58]$. Previous studies have shown that injection of capsaicin into the hindpaw produced ERK activation in the spinal cord, while blockade of spinal ERK1/2 activity via i.t. injection of MEK inhibitor U0126 decreased nocifensive responses induced by formalin, capsaicin, CG or complete Freund's adjuvant [59-61].

Corroboration of the local action of bergamot essential oil and linalool was provided by Katsuyama and collaborators [62]. The nocifensive response to formalin (licking and biting) was considerably decreased in both phases of the formalin test following intraplantar administration of bergamot essential oil or linalool into the ipsilateral, but not the contralateral, hindpaw of male ddY-strain mice. These findings show the peripheral antinociceptive action of both compounds, which was antagonized by intraplantar and i.p. injection of naloxone hydrochloride and naloxone methiodide, and confirm previous reports that suggest the involvement of peripheral opioid receptors in antinociception induced by bergamot essential oil and linalool [62].

In traditional Chinese medicine, frankincense from Boswellia carterii is commonly used for topical treatment of pain and inflammation [63]. A study carried out to investigate the antinociceptive and anti-inflammatory action of frankincense oil and water extracts and three of its main componentes, i.e., linalool, $\alpha$-pinene and 1-octanol, via xylene-induced ear edema and a formalin-inflamed hindpaw model in male Kunming mice, showed consistent evidence about their anti-inflammatory and analgesic effects. Frankincense oil extract, which contains more linalool, $\alpha$-pinene and 1-octanol than frankincense water extract, produced a faster and more effective reduction of the swelling and pain than the water extract. In addition, the combination of linalool, $\alpha$-pinene and 1-octanol exhibited stronger biological effect on hindpaw inflammation and COX-2 overexpression than the three compounds used separately, indicating that they contribute to the topical antinociceptive and anti-inflammatory properties of frankincense by inhibiting COX-2 activation [64].

A study by Tashiro and collaborators [65] reported the antinociceptive effect of linalool in a different experimental protocol using vapour exposure mediated by hypothalamic orexin neurons, one of the main mediators in the behavioral responses to pain [66]. The involvement of these cells was evidenced by a significant increase in the number of c-Fos-expressing orexin neurons, and in linalool odour-exposed and odourless air-exposed orexin neuron-ablated mice that exhibited similar pain behavior in the first and second phase of the formalin test. The confirmation of the contribution of orexinergic transmission was shown in orexin peptide-deficient mice exposed to linalool vapour in which linalool failed to evoke antinociceptive effects after formalin-induced insult, suggesting the participation of orexinergic transmission in linalool odour-induced antinociceptive response. Moreover, linalool odour exposure significantly decreased pain response in both phases of the formalin test in mice (wild type: C57BL16) while, in the hot plate test, it increased the latency of hindpaw withdrawal when compared with the odourless air control following an injurious heat stimulus. In the investigation of the participation of olfactory processing in linalool analgesic effects by chemical nociceptive stimulus (formalin test), pain behavior in olfactory bulbectomized mice under linalool vapour exposure did 
not differ markedly from the odourless air group in both phases of the test. In the anosmic model using mice with a nonfunctional olfactory epithelium, no effects of linalool vapour were observed, providing further evidence that the olfactory response produced by linalool vapour may play a key role in inducing analgesic effects [65].

Despite the biological properties of (-)-linalool, its use in the treatment of painful and inflammatory disorders is still limited due to poor oral availability $[67,68]$. A comparative study using experimental pain models (i.e., acetic acid-induced writhing, formalin and hot plate) in male Swiss mice examined the antinociceptive effect of $(-)$-linalool and $\beta$-cyclodextrin $(\beta-C D)$ complexed (-)-linalool (20 or $40 \mathrm{mg} / \mathrm{kg}$, p.o.). Both compounds effectively reduced the nocifensive response in all chemical and heat-induced tests, suggesting the involvement of peripheral and central antinociceptive mechanisms. In the writhing test, the antinociceptive effects were antagonized by naloxone, implying the involvement of the opioidergic neurotransmission pathway. (-)-Linalool and (-)-linalool/ $\beta-C D$ complex also inhibited total leukocyte migration and TNF- $\alpha$ levels in peritoneal fluid in the CG-induced peritonitis protocol. However, $(-)$-linalool $/ \beta-C D$ complex exhibited stronger antinocicptive effect than (-)-linalool alone, indicating once again that cyclodextrin may become a relevant tool to improve the biological activity of water-insoluble monoterpenes [67].

Furthermore, the antinociceptive effect of (-)-linalool and $\beta-\mathrm{CD}$ complexed (-)-linalool was demonstrated in an animal model of chronic noninflammatory muscle pain (fibromyalgia animal model) [69], corroborating the findings by Quintans-Júnior and collaborators [67]. After exposure of male Swiss mice to (-)-linalool and (-)-linalool $/ \beta$-CD complex $(25 \mathrm{mg} / \mathrm{kg}$, p.o.), the animals were tested for mechanical hyperalgesia (von Frey), motor coordination (rotarod), and muscle strength (grip strength meter) for 27 days. Both compounds markedly suppressed mechanical hyperalgesia in the model for fibromyalgia, persisting for $24 \mathrm{~h}$ only in the linalool complexed in $\beta$-cyclodextrin group. Additionally, the assessment of the areas in the central nervous system involved in antihyperalgesic activity by a method for immunofluorescence labeling of fos protein showed that both compounds effectively activated neurons of the locus coeruleus, nucleus raphe magnus and periaqueductal gray areas, suggesting the participation of descending pain pathways in the improved antinociceptive effect of (-)-linalool/ $\beta-C D$ complex [69].

\subsection{Eugenol}

Eugenol (2-methoxy-4-(2-propenyl) phenol) is a phenylpropanoid found as the main constituent of Eugenia aromatica (L.) Baill (clove oil, Myrtaceae) [70,71], being commonly used as an analgesic and anti-inflammatory in dental procedures, e.g., pulpitis and dentinal hypersensitivity [71-73]. Other phamacological properties of this compound include neuroprotective [74], anticonvulsant [75], antipyretic [76], and reduction of neuropathic [77] and orofacial pain [78]. The administration of eugenol (1-10 $\mathrm{mg} / \mathrm{kg}$, p.o.) has been reported to produced dose-dependent antinociceptive effects in male ICR mice (a strain of albino mice originated from the Institute of Cancer Research in the United States) tested in the acetic acid-induced writhing test-an effect that lasted for at least $30 \mathrm{~min}$-and to inhibit the nociceptive behavior in the second phase of the formalin test as well as the nocifensive response time (reduced licking, scratching and biting of the lumbar or caudal region) for intrathecal injection of substance $P$ (a neuropeptide associated with inflammatory processes and pain) or glutamate. Intraperitoneal pretreatment with naloxone and yohimbine ( $\alpha 2$-adrenergic receptor antagonist) antagonized the analgesic effect of eugenol in the writhing test, whereas no such action was observed after pretreatment with methysergide (5-hydroxytryptamine (5-HT) serotonergic receptor antagonist) [73]. Bó and collaborators [71] provided more information about the mechanisms involved in the effect of eugenol on acute pain by indicating the participation of glutamatergic and TNF- $\alpha$ pathways. In the acetic acid-writhing test, exposure to eugenol (3-300 $\mathrm{mg} / \mathrm{kg}$, p.o., $60 \mathrm{~min}$ or i.p., $30 \mathrm{~min}$ ) suppressed $82 \pm 10 \%$ and $90 \pm 6 \%$ of the nociceptive response of male Swiss mice ( $\mathrm{ID}_{50}$ values of 51.3 and $50.2 \mathrm{mg} / \mathrm{kg}$, respectively) while, in the glutamate test, eugenol (0.3-100 mg/kg, i.p.) decreased the response behavior by $62 \pm 5 \%$ (ID 50 of $5.6 \mathrm{mg} / \mathrm{kg})$ - An effect that 
was reversed by naloxone. The administration of eugenol $(10 \mathrm{mg} / \mathrm{kg}$, i.p.) inhibited the nociception induced by the intrathecal (i.t.) injection of glutamate (37 $\pm 9 \%)$, kainic acid (kainite) $(41 \pm 12 \%)$, $\alpha$-amino-3-hydroxy-5-methyl-4-isoxazolepropionic acid (AMPA) (55 $\pm 5 \%$ ), substance P (SP) ( $39 \pm 8 \%$ ), and biting behavior induced by TNF- $\alpha(65 \pm 8 \%)$. These findings give further evidence for the involvement of the opioid receptors in the antinociceptive action of eugenol and suggest that the mechanism of action also seems to include the modulation of glutamatergic receptors (i.e., kainate and AMPA), and the inhibition of TNF- $\alpha$.

Eugenol is also the major constituent of the essential oil of Ocimum gratissimum L. (Lamiaceae), a plant popularly used in the treatment of painful diseases. In a model of neuropathic pain induced by chronic constriction of the sciatic nerve, the oral exposure to eugenol and the monoterpene myrcene ( 5 or $10 \mathrm{mg} / \mathrm{kg}$, for 14 days after surgery) produced antihypernociceptive effects on male C57BL/6J mice tested in mechanical (von Frey) and thermal (hot plate) tests [79]. In addition, the administration of eugenol $(1,5$ and $10 \mathrm{mg} / \mathrm{kg})$ markedly decreased IL-1 $\beta$ levels whereas no significant effect was caused by treatment with myrcene. Similar antihypernociceptive activity was obtained with $O$. gratissimum essential oil ( 20 and $40 \mathrm{mg} / \mathrm{kg}$ ) in the neurophatic pain models, providing evidence for the biological action that supports its popular use [79].

The evaluation of the antinociceptive effect of eugenol in a monoiodoacetate-induced osteoarthritis model revealed that daily administration of eugenol $(40 \mathrm{mg} / \mathrm{kg}$, p.o.) to Sprague Dawley rats during four weeks significantly changed gait parameters (e.g., swing speed, swing phase duration and duty cycle) of the treated hindlimb and reduced secondary mechanical allodynia in the first and the third week of treatment (measurement of withdrawal threshold in response to von Frey filaments). Spinal pain-related peptide analysis showed reduced expression of substance P and calcitonin gene-related peptide (CGRP) and increased levels of dynorphin (an opioid peptide) in animals exposed to eugenol [80]. It is known that the pharmacological inhibition of Transient Receptor Potential Vanilloid 1 (TRPV1) lowers the secretion of substance P [81] and as eugenol acts in the central nervous system, this may account for the decrease in substance P content [77]. Furthermore, the decrease in CGRP could be related to reduced activity of the rat knee joint afferent fibres since, like substance P, CGRP is also present in these cells [80,82]. These results indicate an effective antinociceptive action of eugenol to attenuate osteoarthritis-related pain [80].

In an experimental procedure using a half-tongue model in humans, Klein and collaborators [83] demonstrated that eugenol and carvacrol induced temporally desensitinzing patterns of oral irritation and increased innocuous warmth and noxious heat sensation on the tongue. The irritant sensation caused by both compounds was reduced during repeated applications at a $1 \mathrm{~min}$ interstimulus interval (self-desensitization) which lasted for at least $10 \mathrm{~min}$. Cross-desensitization of capsaicin-evoked irritation was also observed. Eugenol and carvacrol elicited a significant increase in the magnitude of perceived innocuous warmth for at least $10 \mathrm{~min}$, and briefly (less than $5 \mathrm{~min}$ ) intensified heat pain at a $49^{\circ} \mathrm{C}$ stimulus. It was suggested that the short-lived hyperalgesia after eugenol exposure may be associated with TRPV3-mediated improvement of thermal gating of TRPV1 present in lingual polymodal nociceptors [83].

Xixin (Asari Radix et Rhizoma) is a traditional herbal medicine used in China, Japan, and Korea as a local anesthetic, in inflammatory diseases, and to releave toothache and headache [84]. Methyl eugenol (4-allyl-1,2-dimethoxybenzene), a structural analogue of eugenol, is the main active component isolated from Xixin, known to possess antinociceptive, anesthetic, anticonvulsant, hypothermic and myorelaxant properties $[75,85,86]$. An in vitro study using cDNA clone of pNaEx8 plasmid encoding the Nav1.7 $\alpha$ subunit transiently expressed in Chinese hamster ovary (CHO) cells showed the inhibitory effect of methyl eugenol on Nav1.7 channels as a mechanism involved in its antinociceptive and anesthetic actions [86]. Methyl eugenol tonically suppressed peripheral nerve Nav1.7 currents in a dose- and voltage-dependent manner in the whole-cell patch-clamp method ( $\mathrm{IC}_{50}$ of $295 \mu \mathrm{moL} / \mathrm{L}$ at a $-100 \mathrm{mV}$ holding potential). Functionally, methyl eugenol expressed higher affinity to Nav1.7 channels in the inactivated and/or open state, indicating that, when in 
the presence of methyl eugenol, Nav1.7 channels presented decreased availability for activation in a steady-state inactivation protocol, strong use-dependent inhibition, increased binding kinetics, and slow recovery from inactivation compared to untreated channels. This suggests that the antinociceptive and anesthetic properties of methyl eugenol may be a consequence of the inhibitory effect of this compound on peripheral sodium channels [86].

In addition to methyl eugenol, another compound known as ortho-eugenol, a synthetic isomer of eugenol, has also been reported to cause antinociceptive and anti-inflammatory effects. In a study by Fonsêca and collaborators [87], the administration of ortho-eugenol (50, 75 and $100 \mathrm{mg} / \mathrm{kg}$, i.p.) to male Swiss mice tested in the acetic acid writhing and glutamate tests caused a significant reduction in the number of writhes and in the licking time, respectively. The animals presented increased reaction time from thermal stimulus in the hot plate test, but treatment with yohimbine antogonized the antinociceptive activity, indicating a possible mechanism of action involving the adrenergic system. The anti-inflammatory action of ortho-eugenol was evidenced in inflammatory protocols, including the acetic acid-induced peritoneal permeability and the CG-induced peritonitis, which showed a suppressive effect on vascular permeability and leukocyte migration and the subsequent reduction of TNF- $\alpha$ and IL-1 $\beta$ due to inhibition of NF- $K B$ and p38 phosphorilated forms observed in the peritonitis test.

\subsection{Menthol}

Menthol and L-menthol, predominant analgesic menthol isomer in medicinal preparations [88] is a natural cooling compound in peppermint oil from mint plants, and is found in various commercial products, e.g., toothpast, chewing gum and topical analgesics [89]. Low to moderate concentrations of topically applied menthol has been shown to inhibit capsaicin irritancy, sprains, heat hypersensitivity and headaches [90-94], while high concentrations (topical use or intraplantar injection) generated cold allodynia and hyperalgesia [94-97]. In addition, patients with neuropathic pain have been reported to also exhibited increased analgesic response induced by menthol [96].

The central mechanisms of analgesia induced by menthol was investigated by Pan and collaborators [94] in an in vitro assay using primary cultures of spinal cord superficial dorsal horn neurons obtained from 2- to 4-day-old CD-1 mouse pups, and in vivo by use of CD-1 male mice (50 and $100 \mathrm{mg} / \mathrm{kg}$, i.p.). The results obtained showed that exposure to menthol caused dose-dependent reduction of ipsilateral and contralateral pain hypersensitivity induced by complete Freund's adjuvant; reduction of nociceptive behavior in both phases of the formalin test; dose-dependent and $\mathrm{Cl}^{-}$-mediated generation of inward and outward currents in cultured dorsal horn neurons, indicating the activation of $\gamma$-aminobutyric acid type A receptors; blockage of voltage-gated sodium channels and voltage-gated calcium channels in a voltage-, state-, and use-dependent manner; decrease in the repetitive firing and action potential amplitude; reduced neuronal excitability, and interruption of spontaneous synaptic transmission of cultured superficial dorsal horn neurons.

In the peripheral mechanisms involved in the effects displayed by menthol, activation of transient receptor potential cation channel subfamily M member 8 (TRPM8) and TRPA1 channels is believed to play an important role in menthol-induced cold hyperalgesia $[97,98]$. In fact, previous studies have shown that menthol reversed cinnamaldehyde-induced heat hyperalgesia, an effect that may have been a consequence of TRPA1 blockage by this compound [99,100]. In a study by Roberts and collaborators [46], the sensory effects and interactions of topically applied-TRP agonists menthol (TRPM8), capsaicin (TRPV1) and cinnamaldehyde (TRPA1) to the skin of 14 health humans were assessed through changes in thermal sensibility and contact heat-evoked potentials (CHEP). The application of menthol provoked cold hypersensitivity while cinnamaldehyde and capsaicin produced heat hyperalgesia. Furthermore, menthol and cinnamaldehyde did not exert any effect on evoked potentials, but the amplitude of CHEP and evoked pain ratings were negatively correlated after capsaicin exposure. 
Other studies revealed the participation of TRPM8 as the main mediator of menthol- (or L-arginine)-induced analgesia of acute and inflammatory pain [88,101]. For instance, L-arginine (10 and $20 \mathrm{mg} / \mathrm{kg}$, i.p.) significantly reduced pain behavior in the hot plate, acetic acid writhing and tail flick, and inflammatory (complete Freund's adjuvant) tests. It effectively inhibited nocifensive behavior (licking, fliching or biting) caused by specific pharmacological activation of TRPV1 when administered in combination with capsaicin ( $5 \mathrm{nmoL}$; menthol $-50 \mathrm{nmoL}$-intraplantar injection) in wild-type mice, but not in Trpm8-/-mice. Similar results were obtained following exposure of wild-type and Trpm8-/-mice to L-arginine ( $50 \mathrm{nmoL})$ coinjected with acrolein ( $25 \mathrm{nmoL}$; intraplantar), an agonist of TRPA1 in sensory nerves. More importantly, the antinociceptive activity of L-arginine was completely eliminated by genetic deletion of TRPM8, and its antinociceptive effect was restored in mice treated with AMG2850, a selective TRPM8 inhibitor. The selective activation of TRPM8 with WS-12 (a menthol derivative and a specific TRPM8 agonist) in cultured sensory neurons and in vivo also produced TRPM8-dependent antinociception of acute and inflammatory pain. L-arginine and WS-12 effects were counteracted by naloxone, indicating the participation of endogenous opioid-dependent analgesia pathways [88].

The effects of menthol on human embryonic kidney-derived $293 \mathrm{~T}$ cells expressing (h)TRPV1 and of capsaicin on hTRPM8 were addressed in vitro and showed that the activation of hTRPV1 currents by heat and capsaicin were suppressed by menthol, whereas activation of hTRPM8 currents were suppressed by capsaicin [101]. Moreover, an in vivo sensory irritation test carried out in Japanese males $(20-30$ years old; $n=10)$ demonstrated that menthol exhibited antinociceptive effect on the sensory irritation caused by a capsaicin analogue. These results suggest an interaction between TRPV1 and TRPM8 agonists and both of these channels, and since TRPM8 is not usually coexpressed with TRPV1 in primary afferent neurons [102,103], it is possible that the information transmitted by TRPM8- and TRPV1-expressing neurons could affect each other. Therefore, it is believed that menthol-induced TRPM8-mediated cold sensation could be improved by the inhibition of TRPV1 and that capsaicin-induced TRPV1-mediated heat sensation could be increased by the inhibition of TRPM8 [101].

\section{6. (-)- $\alpha$-Bisabolol}

(-)- $\alpha$-Bisabolol (6-methyl-2-(4-methylcyclohex-3-en-1-yl)-hept-5-en-2-ol) is a sesquiterpene alcohol present in essential oils of various plant species such as Vanillosmopsis and Peperonia [104,105]. This compound has a soft floral odour, being its most popular example the species Matriarca chamomilla, known as chamomile $[106,107]$. The pharmacological properties attributed to $(-)-\alpha$-bisabolol include wound healing [108], gastroprotective [109], antitumor [110], antioxidant [111], leishimanicidal [112], and peripheral nervous blocker [113].

In 2011, Leite and collaborators [114] and Rocha and collaborators [107] evidenced the antinociceptive and anti-inflammatory activities of $(-)-\alpha$-bisabolol through various rodent models of nociception and inflammation. In the acetic acid-induced writhing, formalin and hot plate tests, (-)- $\alpha$-bisabolol (25 or $50 \mathrm{mg} / \mathrm{kg}$, p.o.) administered to male Swiss mice reduced the number of writhings, showing stronger effect $(54.68 \%$ and $4.24 \%$, respectively) than the reference drug indomethacin $(10 \mathrm{mg} / \mathrm{kg}$, p.o.; $48.52 \%)$; diminished paw-licking time in the second phase of the formalin test $(92.95 \%$ and $92.74 \%$, respectively), but did not affect the response time to heat in the hot plate, suggesting that (-)- $\alpha$-bisabolol has no central antinocicetive effect [115]. Significant inhibition of nociceptive behavior by (-)- $\alpha$-bisabolol (50, 100 or $200 \mathrm{mg} / \mathrm{kg}$, p.o.) was also demonstrated in the cyclophosphamide and mustard oil-induced visceral nociception tests [114].

In the inflammatory models of dextran- and CG-induced paw edema, edema formation after intraplantar injection of these compounds was effectively suppressed by $(-)-\alpha$-bisabolol (100 and $200 \mathrm{mg} / \mathrm{kg}$, p.o.) pretreatment in male Swiss mice. (-)- $\alpha$-Bisabolol (100 and $200 \mathrm{mg} / \mathrm{kg}$ ) significantly inhibited myeloperoxidase (MPO) activity and decreased TNF- $\alpha$ levels in the peritoneal fluid of rats with induced peritonitis. This result indicates that $(-)-\alpha$-bisabolol blocks neutrophil migration to the 
peritoneal cavity as indicated by MPO, a marker of the presence of these cells [115]. Moreover, the edematogenic response triggered by croton oil, arachidonic acid and phenol in the mouse ear edema was significantly decreased by topically applied (-)- $\alpha$-bisabolol $(0.7$ and $1.4 \mathrm{mg} /$ ear); however, it did not effectively reduce edema induced by caipsaicin, indicating that $(-)-\alpha$-bisabolol action mechanism does not involve activation of TRPV1 receptor [114].

The antinociceptive action of (-)- $\alpha$-bisabolol (50, 100 and $200 \mathrm{mg} / \mathrm{kg}$, i.p.) was also reported by Leite and collaborators [115] in visceral nociceptive models induced by acetic acid, formalin, capsaicin and mustard oil. To investigate the mechanisms involved in its effects, prior to exposure to $(-)-\alpha$-bisabolol $(50 \mathrm{mg} / \mathrm{kg})$ in the acute model of visceral nociception induced by intracolonic instillation of mustrad oil, male Swiss mice were treated with $\mathrm{N}(\mathrm{G})$-Nitro-L-arginine methyl ester (L-NAME), yohimbine, glibenclamide, ondansetron or ruthenium red in order to confirm the participation of nitrergic, noradrenergic, $\mathrm{K}_{\mathrm{ATP}}+, 5-\mathrm{HT}_{3}$, and TRPV1 receptors in the effect of this compound. Treatment with (-)- $\alpha$-bisabolol and ruthenium red (non competitive antagonist of TRPV1) in combination resulted in an additive antinociceptive effect, while the results obtained with (L-NAME, NO synthase inhibitor) and ondansetron (5- $\mathrm{HT}_{3}$ antagonist) were inconclusive. Yohimbine $(\alpha-2$ adrenoceptor) failed to antagonize (-)- $\alpha$-bisabolol action, indicating that $\alpha 2$ adrenoceptor is not involved in the attenuation of visceral nociception. In addition, (-)- $\alpha$-bisabolol $(50 \mathrm{mg} / \mathrm{kg}) \mathrm{did}$ not suppress capsaicin-induced visceral nociception, corroborating previous findings showing that this compound does not act as a TRPV1 agonist [114].

By the use of imaging, electrophysiological and biochemical methods, Nurulain and collaborators [116] showed that (-)- $\alpha$-bisabolol reversibily and dose-dependently suppressed $\alpha 7$-nicotinic acetylcholine receptors ( $\alpha 7$-nChRs) mediated currents in oocytes of Xenopus laevis. These receptors are found in the peripheral and central nervous system and are characterized by rapid desensitization and high permeability to calcium [117]. The obtained results revealed that the suppressive effect of $\left(--\alpha\right.$-bisabolol $\left(\mathrm{IC}_{50}=3.1 \mu \mathrm{M}\right)$ was not altered after injection of calcium chelator BPTA and perfusion with calcium-free solution containing barium, which is indicative of the non-involvement of endogenous calcium-dependent $\mathrm{Cl}^{-}$channels in (-)- $\alpha$-bisabolol activities. Furthermore, the effect of $(-)$ - $\alpha$-bisabolol on $\alpha 7$-nChRs were investigated in the first region in the hippocampal circuit known as CA1 region of stratum radiatum interneurons of rat hippocampal slices (whole-cell patch-clamp method) and was shown to have an inhibitory action in choline-induced currents in the CA1 interneurons [116,117].

Stachys lavandulifolia Vahl (Lamiaceae) is a plant used in Turkish and Iranian folk medicine as an analgesic and anti-inflammatory [118]. A study by Barreto and collaborators [118,119] provided information about the antinociceptive and anti-inflammatory effects displayed by the main compound of S. lavandulifolia essential oil, i.e., (-)- $\alpha$-bisabolol, in models of orofacial nociception. Male Swiss mice exhibited reduced face-rubbing behavior after exposure to (-)- $\alpha$-bisabolol (50 $\mathrm{mg} / \mathrm{kg}$, p.o. -first phase; 25 and $50 \mathrm{mg} / \mathrm{kg}$, p.o. -second phase) in the formalin test. Further analysis of the pharmacological profile showed its effective inhibitory effect $(25$ and $50 \mathrm{mg} / \mathrm{kg}$ ) on the nociceptive response in animals tested in the capsaicin- and glutamate-induced orofacial pain tests. The data presented in the pain models indicated a stronger effect of (-)- $\alpha$-bisabolol in comparison with $S$. lavandulifolia essential oil. In the CG-induced pleurisy, (-)- $\alpha$-bisabolol exhibited a significant anti-inflammatory activity and this result could be possibly related to the significant decrease in the level of TNF- $\alpha$ in pleural inflammatory exudate. No considerable alteration was observed in the level of IL-1 $\beta$, but in contrast S. lavandulifolia essential oil markedly reduced both pro-inflammatory cytokines. These findings support the folk use of S. lavandulifolia and relates its antinociceptive and anti-inflammatory actions to (-)- $\alpha$-bisabolol [119].

\subsection{Cinnamaldehyde}

Cinnamaldehyde (CIN) is a naturally occurring phenylpropanoid and has been described as the most important component present in the volatile oil of different cinnamon species [120]. This component contributes to the fragrance and several biological properties observed in Cinnamomum 
species, including antioxidant, antipyretic, antimicrobial and anti-inflammatory activities [121-124]. For example, Cinnamomum zeylanicum essential oil exhibited antinociceptive properties on acute and chronic pain in mice, and CIN seems to be involved in C. zeylanicum antinociceptive effect [124]. In 2011, Roberts and collaborators [46] investigated the sensory effects, with emphasis on thermal sensibility, of CIN together with capsaicin (CAP) and menthol (MEN) in a human experimental pain model. Fourteen healthy human participants received topically on the skin an unguent containing three concentrations of CIN $(1 \%, 5 \%$ and $10 \%)$, CAP $(0.075 \%, 1 \%$ and $3 \%)$ or $\operatorname{MEN~}(2.5 \%, 5 \%$ and $10 \%)$. Topical CAP caused a noteworthy heat hyperalgesia. MEN provoked a cooling sensation, whereas CIN caused heat hypersensitivity at all tested concentrations. However, CIN and MEN did not present effect on evoked potentials. Further, the intensity of CIN induced heat hyperalgesia was amplified by secondary compound CAP, indicating an additive effect [46].

In another study, it was investigated the antinociceptive effect of CIN in both peripheral and central pain models (acetic acid induced writhing and Eddy's hot plate methods, respectively) as well as its combination with two standard drugs (diclofenac sodium and pentazocine) in mice. CIN was able to reduce nociception in a dose-dependent manner, decreasing the number of writhes $54 \%$ and $81 \%$ at concentrations of 100 and $200 \mathrm{mg} / \mathrm{kg}$, respectively. On the other hand, it was also observed a significant reduction in writhings $(84.43 \%)$ when CIN $(100 \mathrm{mg} / \mathrm{kg})$ was co-administered with diclofenac sodium $(2.5 \mathrm{mg} / \mathrm{kg})$. In Eddy's hot plate method, CIN exhibited hyperalgesic behavior when given alone as well as decreased the antinociceptive effect of pentazocine in combination group (CIN $100 \mathrm{mg} / \mathrm{Kg}+$ pentazocine $2.5 \mathrm{mg} / \mathrm{Kg}$ ). These data demonstrate that CIN considerably enhanced the antinociceptive effect of diclofenac sodium at the same time as inhibited the antinociceptive action of pentazocine [125].

\subsection{Citronellal}

Citronellal (CTAL), also named rhodinal, is an acyclic monoterpenoid aldehyde known for its capacity to repel insects [126]. CTAL is one of the main responsible for the lemon-scent of many of the plants of the Cymbopogon genus (Poaceae), especially the species C. nardus [127,128], C. winterianus [127] and C. citratus [128]. In previous study, C. winterianus essential oil demonstrated noteworthy antinociceptive, anti-inflammatory and antioxidant properties, and the monoterpene CTAL seems to be involved in these effects $[129,130]$. For this reason, the antinociceptive effect of CTAL (50, 100 or $200 \mathrm{mg} / \mathrm{kg}$, i.p.) was investigated in three experimental nociception models: formalin test, capsaicin test and glutamate-induced nociception. CTAL, in all tested doses, caused a dose-dependent reduction in the pain-related behaviors during both phases of the formalin test and was naloxone-sensitive. Similarly, this monoterpene also significantly decreased face-rubbing behavior induced by administration of capsaicin or glutamate, suggesting that CTAL possesses antinociceptive action [130].

In another study, it was examined the effect of CTAL on inflammatory nociception induced by different stimuli in mice as well as the involvement of the NO-cGMP-ATP-sensitive $\mathrm{K}^{+}$channel pathway. CTAL $(25,50$ or $100 \mathrm{mg} / \mathrm{kg}$, i.p.) exhibited a significant reduction of the mechanical nociception induced by tumor necrosis factor $\alpha(\mathrm{TNF}-\alpha)$ and carrageenan in all studied doses. This monoterpene also significantly decreased the mechanical nociception in the dopamine (DA) test at doses of 25 and $100 \mathrm{mg} / \mathrm{kg}$, and in the prostaglandin $\mathrm{E}$ type $2\left(\mathrm{PGE}_{2}\right)$ test only at higher dose $(100 \mathrm{mg} / \mathrm{kg})$. Interestingly, pretreatment with L-NAME or glibenclamide reversed the antinociceptive effect of the CTAL $(100 \mathrm{mg} / \mathrm{kg})$ on $\mathrm{PGE}_{2}$-induced mechanical nociception, suggesting that CTAL inhibits mechanical nociception through the involvement of NO-cGMP-ATP-sensitive $\mathrm{K}^{+}$channel pathway. Taken together, these results show the potential of CTAL for the treatment of pain [131].

\subsection{Citronellol}

Citronellol (CTOL), or dihydrogeraniol, is a natural alcoholic monoterpene found in essential oils of various aromatic plant species [132,133]. CTOL exists in nature as two enantiomers, designated $R-(+)$ and $S-(-) . R-(+)-C T O L$ is widely found in citronella oils, such as Cymbopogon winterianus, and is 
the more common isomer [134]. On the other hand, S-(-)-CTOL is commonly found in rose [135] and geranium oils [136]. Different essential oils containing this monoterpene have been described in the literature to possess antinociceptive and anti-inflammatory effects, including C. winterianus, C. citratus and Pelargonium graveolens [130,137,138]. With this feedback, Brito and collaborators [139] evaluated the antinociceptive and anti-inflammatory activities of CTOL, in mice, using different experimental models for pain and inflammation: acetic acid-induced abdominal constrictions, formalin-induced nociception, hot plate test and carrageenan-induced pleurisy. CTOL, in all tested doses $(25,50$ or $100 \mathrm{mg} / \mathrm{kg}$, i.p), reduced the total number of writhing in acetic acid-induced abdominal constriction test. This monoterpene also decreased paw licking times during both the early and later phases of the formalin test at doses of 25,50 and $100 \mathrm{mg} / \mathrm{kg}$. In the hot plate test, CTOL caused a marked increase in the latency time of the animals only at the higher dose. Finally, pretreatment with CTOL was also capable to reduce, in a dose-dependent fashion, both neutrophil infiltration and the levels of TNF- $\alpha$ in the exudates from carrageenan-induced pleurisy. These data indicate that CTOL exhibits an interesting antinociceptive and anti-inflammatory effect, and its mechanism of action probably involves inhibition of peripheral mediators as well as central inhibitory mechanisms [139].

Giving continuity to the study performed by Brito and collaborators [139], Brito and collaborators [140] evaluated the antinociceptive effects of CTOL on orofacial nociception in mice as well as a possible central nervous system (CNS) involvement. Pretreatment with CTOL at doses of 25, 50 and $100 \mathrm{mg} / \mathrm{kg}$ (i.p.) was able to reduce nociceptive behavior in both phases of the formalin test and in the capsaicin test. Similarly, CTOL, in all assayed doses, decreased the nociceptive face-rubbing behavior in glutamate-induced orofacial nociception model. Additionally, to investigate the action of the CTOL on CNS, it was performed an immunofluorescence protocol for Fos protein. The obtained results revealed that CTOL was capable to induce a significant increase in the average number of neurons in the piriform and retrosplenial cortex, olfactory bulb and periaqueductal grey. Taken together, these data suggest that CTOL decreases orofacial nociceptive behavior and this effect involves, at least in part, the activation of CNS regions, mainly periaqueductal and grey retrosplenial cortex [140].

In another study, it was investigated the antihyperalgesic effect of CTOL in mice using several experimental models of hyperalgesia. The mechanical hyperalgesia was induced by four hyperalgesic agents: carrageenan (CG), TNF- $\alpha, \mathrm{PGE}_{2}$ or dopamine. Pretreatment with CTOL, in all tested doses $(25,50$ or $100 \mathrm{mg} / \mathrm{kg}$, i.p.), was capable to attenuate mechanical hyperalgesia induced by CG, TNF- $\alpha, \mathrm{PGE}_{2}$ and DA in the acute models of inflammatory nociception as well as reduce the edema formation. Additionally, it was also evaluated the involvement of the spinal cord lamina I in this antihyperalgesic effect. The immunofluorescence protocol showed that CTOL significantly decreased the average number of neurons presenting Fos protein, indicating that the action of CTOL on mechanical hyperalgesia occurs, at least in part, via inhibition of the spinal cord lamina I [141].

\subsection{Citronellyl Acetate}

Citronellyl acetate (CAT), known for its pleasant smell, belongs to the family of fatty alcohol esters and is frequently used as flavor and fragrance agent [142]. CAT is present mostly in Eucalyptus citriodora [143], but also is found in minor quantities in the volatile extract from dried pericarp of Zanthoxylum schinifolium [144]. Since there are few studies investigating the biological potential of this monoterpene and E. citriodora essential oil possesses antinociceptive and anti-inflammatory effects [145], Rios and collaborators [142] investigated the antinociceptive effect of CAT in both physically- and chemically-induced acute pain models as well as the possible antinociceptive mechanisms involved. CAT $(25,50,75,100$ or $200 \mathrm{mg} / \mathrm{kg}$, i.g.), at two higher doses, caused a significant reduction of acetic acid-induced abdominal constrictions in mice. In the formalin test, CAT (100 or $200 \mathrm{mg} / \mathrm{kg}$, p.o.) reduced nociceptive behavior in both the early and later phases. Similarly, in the glutamate test, CAT decreased nociceptive behavior after pretreatment with the doses of 100 and $200 \mathrm{mg} / \mathrm{kg}$ (p.o.). Regarding the mechanism of action, the results showed that, at least in part, protein 
kinase $\mathrm{C}$ (PKC) and protein kinase A (PKA), transient receptor potential vanilloid 1 (TRPV1), TRPM8, acid-sensing ion (ASIC) and glutamate receptors are involved in the antinociceptive effect of CAT.

\subsection{1. $\alpha$-Phellandrene}

$\alpha$-Phellandrene ( $\alpha$-PHE), a cyclic monoterpene, is a natural compound that can occur in two enantiomeric forms: (-)- $\alpha$-PHE and (+)- $\alpha$-PHE. $\alpha$-PHE is present in the volatile oil of several plants and in varied concentrations [146], such as Anethum graveolens (32\%) [147], Solanum erianthum (17.5\%) [148], Schinus terebinthifolius (15.7\%) [149], Curcuma zedoaria (14.9\%) [150], Thymus kotschyanus (10.8\%) [151] and Cupressus atlantica (5.5\%) [152]. Furthermore, this constituent has been associated with the antinociceptive and anti-inflammatory properties of some species, including Matricaria chamomilla [153], Schinus polygamus [154] and Zingiber officinale [155]. In 2012, Lima and collaborators [156] studied the antinociceptive and anti-inflammatory effects of $\alpha$-PHE in five experimental nociception models (acetic acid-induced abdominal writhing, formalin test, capsaicin test, glutamate test and carrageenan-induced inflammatory hypernociception) as well as the possible antinociceptive mechanisms involved. In the writhing and capsaicin tests, $\alpha$-PHE $(3.125,6.25$ or $12.5 \mathrm{mg} / \mathrm{kg}$, p.o.) exhibited a significant antinociceptive effect in all assayed doses. In the formalin test, $\alpha$-PHE $(50 \mathrm{mg} / \mathrm{kg})$ reduced nociceptive behavior in both first and second phases. In the glutamate test, $\alpha$-PHE $(12.5$ and $25 \mathrm{mg} / \mathrm{kg})$ reduced nociceptive response in a dose dependent manner. In carrageenan-induced hyperalgesia, this monoterpene significantly reduced the inflammatory hypernociception only at dose of $50 \mathrm{mg} / \mathrm{kg}$. In the study of the involved mechanisms, the antinociceptive effect of $\alpha$-PHE was reversed by pretreatment with various drugs, such as naloxone, atropine, glibenclamide, L-arginine and yohimbine. These results indicate that $\alpha$-PHE possesses noticeable antinociception and some of the possible mechanisms of action involve the opioid, nitrergic, glutamatergic, cholinergic and adrenergic systems [156].

\subsection{2. $\alpha$-Terpineol}

$\alpha$-Terpineol $(\alpha-$ TPN $)$ is monoterpene alcohol that has been isolated from a variety from natural sources, such as the essential oils from Melaleuca leucadendra [157], Citrus aurantium [158] and Nepeta $d s c h u p a r e n s i s$ [159]. There are three isomers, $\alpha-, \beta-$, and $\gamma$-TPN, the latter two differing only by the location of the double bond. Quintans-Júnior and collaborators [160] studied the antinociceptive action of $\alpha$-TPN using heat-induced (hot-plate test) and chemical-induced (acetic acid, formalin, glutamate and capsaicin) nociception models in mice at different doses $(25,50$ or $100 \mathrm{mg} / \mathrm{kg}$, i.p). $\alpha$-TPN, in all tested doses, exhibited a reduction of the nociceptive behavior at the early and late phases of paw licking and reduced the writhing reflex in mice (formalin and writhing tests, respectively). In the glutamate and capsaicin tests, $\alpha$-TPN also reduced remarkably nociceptive response, and this inhibition of antinociceptive behavior was dose-related in capsaicin-induced nociception test. Finally, $\alpha$-TPN significantly increased the latency time in the hot plate test (at only the higher dose). Taken together, these results demonstrate the potential antinociceptive properties of $\alpha$-TPN [160].

\subsection{Vanillin}

Vanillin (VAN), or 4-hydroxy-3-methoxybenzaldehyde, is a phenolic aldehyde with the molecular formula $\mathrm{C}_{8} \mathrm{H}_{8} \mathrm{O}_{3}$. This organic compound contains three highly reactive functional groups in its structure: aldehyde, phenol and ether [161]. VAN is one of the primary chemical constituent extracted from Vanilla planifolia seedpods, a monocotyledonous orchid native of Central America, and is broadly employed as flavoring agents in foods, cosmetics, beverages and pharmaceuticals. Synthetic vanilla is commonly used instead of natural vanilla, since vanilla extract is so much in demand and expensive [161,162]. VAN is known to have several biological activities, including antimutagenic [163], antidepressant [162], antioxidant, hepatoprotective [164] and antitumor [165]. Further, it has been demonstrated the antinociceptive potential of VAN in acetic acid-induced visceral inflammatory pain models [166]. With this feedback, Rathnakar and collaborators [167] investigated the antinociceptive effect of VAN using Eddy's hot plate method. Pretreatment with VAN displayed a significant increase 
in the latency period at both tested doses ( 10 or $100 \mathrm{mg} / \mathrm{kg}$ ). As this experimental model is employed to evaluate the central pain, obtained results indicate a potential central antinociceptive activity probably mediated via opioid receptors [167].

In 2012, Srikanth and collaborators [168] examined the effect of VAN on acute inflammation induced by phlogistic agent carrageenan in rats. These authors observed that pretreatment with VAN $(10,100$ or $200 \mathrm{mg} / \mathrm{kg}$, p.o.) was able to significantly reduce the rat paw edema formation induced by carrageenan at $2 \mathrm{nd}, 3 \mathrm{rd}$ and 4 th hour, and only at the higher doses (100 and $200 \mathrm{mg} / \mathrm{kg}$ ). Further, there are no significant differences between the antioedematogenic effect observed at doses of 100 and $200 \mathrm{mg} / \mathrm{kg}$ [169].

In another study, it was evaluated the antinociceptive and anti-inflammatory effects of VAN on tail flick method and carrageenan-induced rat paw edema model, respectively. Pretreatment with VAN (50 or $100 \mathrm{mg} / \mathrm{kg}$ ) produced a significant inhibition of pain, suggesting that antinociception in the mice tail flick test is mediated probably at the level of the spinal cord. In carrageenan-induced paw edema test, VAN caused a significant reduction in the paw volume at doses of 50 and $100 \mathrm{mg} / \mathrm{kg}$, indicating an anti-inflammatory action [169].

\subsection{Borneol}

Borneol (BOR) belongs to the family of bicyclic monoterpene alcohols and is found in the essential oil of several medicinal plants, such as Lavandula officinalis, Matricaria chamomilla and Valeriana officinalis $[170,171]$. There are three different isomers of BOR, D-(+)-BOR, L-(-)-BOR and isoborneol. Natural BOR contains $98 \%$ of (+)-BOR. (+)-BOR is broadly employed in food and also used in analgesic and anesthetic preparations in traditional Chinese medicine and Japanese medicine [172]. Recent studies have reported that this monoterpenoid possesses a variety of pharmacological effects, including anti-inflammatory [173], vasorrelaxant [174] and neuroprotective activities [175]. Until now, little is known about the specific role of BOR in the pharmaceutical preparations to treat painful and inflammatory conditions. With this feedback, Almeida and collaborators [175] evaluated the antinociceptive and anti-inflammatory activities of BOR, measuring nociception and inflammation in five experimental models in rodents: acetic acid-induced abdominal writhings, formalin-induced nociception, hot plate test, grip strength test and carrageenan-induced peritonitis. BOR $(5,25$ or $50 \mathrm{mg} / \mathrm{kg}$, i.p.) was able to prevent the visceral pain in acetic acid-induced abdominal writhing test in all tested doses. This monoterpene also reduced nociceptive behavior in both the early and later phases of the formalin test at doses of 5,25 and $50 \mathrm{mg} / \mathrm{kg}$. In the hot plate test, BOR caused a marked increase in the latency time (only at higher dose). Additionally, BOR did not cause any significant motor performance alteration in grip strength meter test. Finally, pretreatment with BOR $(5,25$ or $50 \mathrm{mg} / \mathrm{kg}$, i.p.) was able to decrease the leukocyte migration to the peritoneal cavity in peritonitis model induced by carrageenan. These findings indicate that BOR exhibits significant central and peripheral antinociceptive effects as well as anti-inflammatory activity, and without producing motor deficit [175].

In another study, it was investigated the antihyperalgesic activity of BOR on neuropathic and inflammatory pain in different animal models as well as its possible mechanisms of action. BOR (125, 250 or $500 \mathrm{mg} / \mathrm{kg}$, p.o. or i.t.) was able to decrease mechanical hypersensitivity in both segmental spinal nerve ligation-induced neuropathic pain (SNL) and complete Freund's adjuvant-induced chronic inflammatory pain (CFA) models and in a dose-dependent manner. Further, the antihyperalgesic action of this monoterpene, in both SNL and CFA models, was totally reversed by the convulsant alkaloid bicuculline, a selective $\gamma$-aminobutyric acid (A) receptor [GABA(A)R] antagonist. This result suggests that BOR attenuates mechanical hyperalgesia through activation spinal GABAergic transmission in the spinal cord, being a potential candidate for treating chronic pain [176]. 


\subsection{Myrtenol}

Myrtenol (MYR) belongs to the family of bicyclic monoterpene alcohols. This chiral alcohol contains two stereogenic centres and is present in the volatile oil of various aromatic species, including Aralia cachemirica [177] and Tanacetum vulgare [178]. MYR can also be obtained through the selective oxidation of the $\alpha$-pinene [179], and has been reported in the scientific literature by its bioactivity [180-182]. Considering that this monoterpene presents important biological properties and great therapeutic potential, it was evaluated its antinociceptive and anti-inflammatory activities, in mice, using classical models of nociception (acetic acid-induced writhing, hot-plate test and paw licking induced by formalin, glutamate and capsaicin) and inflammation (paw edema induced by different agents, carrageenan-induced peritonitis, myeloperoxidase levels and cytokine measurement). Pretreatment with MYR (25-75 mg/kg, i.p.) effectively inhibited acetic acid-induced nociception; decreased time of licking the paw after the injection of the phlogistic agents glutamate, capsaicin and formalin (only in the second phase); and did not change the latency reaction time in the hot-plate test. In addition, MYR inhibited carrageenan-, histamine-, serotonin compound 48/80- and PGE $_{2}$-induced by paw edema; and also decreased the cell counts, myeloperoxidase activity and cytokine levels of the peritoneal cavity induced by carrageenan. These results suggest that MYR attenuates the nociceptive and inflammatory responses by inhibiting cell migration and also signalling pathway of receptors involved in the transmission of pain [183].

\subsection{Pulegone}

Pulegone (PUL) is a naturally occurring organic compound present in the essential oil from several members of the mint family (Lamiaceae), such as Minthostachys spicata [184], Mentha longifolia [185] and M. pulegium [186]. In nature, PUL occurs in both (+)- and (-)-forms and is classified as a monoterpene ketone [4]. Further, this monoterpenoid has been recognized as being responsible for most of pharmacological effects described for species M. longifolia [185]. In 2011, De Sousa and collaborators [3] investigated the antinociceptive potential of PUL in chemical (formalin test) and thermal (hot plate test) models of nociception. PUL (31.3, 62.5 and $125 \mathrm{mg} / \mathrm{kg}$, i.p.) inhibited dose-dependently both phases of the formalin test, and this effect was not blocked by opioid antagonist naloxone. In hot plate test, PUL augmented significantly the latency reaction time of mice in hot plate in all tested doses $(31.3,62.5$ or $125 \mathrm{mg} / \mathrm{kg})$, confirming that this monoterpene ketone has a central antinociceptive effect [3].

\subsection{Citral}

Citral (CIT) is a mixture of two isomers, cis-isomer neral and trans-isomer geranial, and has been described to be the most important member of the open-chain monoterpenoids. This monoterpene is found in volatile oil of several aromatic herbs, such as Cymbopogon citratus, a species commonly known as lemongrass [28,187]. Lemongrass tea possesses various biological properties described in literature, such as anti-inflammatory, antioxidant, anxiolytic, cytotoxic and antinociceptive activities [188]. The antinociceptive action of CIT was demonstrated in mice submitted to different experimental models of acute and chronic nociception. Pretreatment with CIT (25, 100 or $300 \mathrm{mg} / \mathrm{kg}$, p.o.) inhibited formalin-induced licking in both the neurogenic and inflammatory phases (inhibition of $54 \%$ and $65 \%$ at $300 \mathrm{mg} / \mathrm{kg}$, respectively); prevented and reduced mechanical hyperalgesia without producing any significant motor dysfunction, with a maximum effect at dose of $100 \mathrm{mg} / \mathrm{kg}$; inhibited the nociceptive response (CIT $100 \mathrm{mg} / \mathrm{kg}$ ) induced by glutamate (inhibition of $49 \%$ ) and phorbol 12-myristate 13-acetate (PMA; inhibition of 54\%); markedly attenuated the pain response (CIT $100 \mathrm{mg} / \mathrm{kg}$ ) induced by $N$-methyl-D-aspartic acid (NMDA; inhibition of 54\%), trans-1-amino-1,3-dicarboxycyclopentane (ACPD; inhibition of $77 \%$ ), substance P (inhibition of $42 \%$ ) or cytokine TNF- $\alpha$ (inhibition of $72 \%$ ); and attenuated the nociception (CIT $100 \mathrm{mg} / \mathrm{kg}$ ) to involve significant activation of serotonergic 
systems (via 5- $\mathrm{HT}_{2 \mathrm{~A}}$ receptor). Together, these results display the potential of CIT for the treatment of inflammatory and neuropathic pain [189].

\subsection{Thymol}

Thymol (THY) is a natural monoterpene phenol derivative of cymene, and isomeric with carvacrol [190]. This monoterpene is found mainly in thyme (Thymus vulgaris) essential oil (approximately 47\%) [191,192]. Further, THY presents various biological properties, including antinociceptive effect [191] and inhibition of inflammatory response [192]. It also known that THY inhibits nerve conduction [193], but there are no studies about how this monoterpenoid influences synaptic transmission. For this reason, Xu and collaborators [194] investigated the effect of THY on spontaneous excitatory transmission by applying the whole-cell patch-clamp technique to substantia gelatinosa (SG) neurons of adult rat spinal cord slices, aiming to comprehend how THY modulates synaptic transmission, with an emphasis on transient receptor potential (TRP) activation. It was found that THY increased the frequency of spontaneous excitatory postsynaptic current, a measure of the spontaneous release of L-glutamate onto SG neurons, by activating TRPA1 channels while producing a membrane hyperpolarization without TRP activation in SG neurons [194].

\subsection{Limonene}

Limonene (LIM) is a colorless liquid hydrocarbon belonging to the family of cyclic monoterpenes. There are two isomers, D- and L-LIM, and the more common D-isomer possesses a strong smell of orange. LIM is the major chemical component of citrus oils [195], but also is found in other aromatic plants species, including Lippia alba [196] and Artemisia dracunculus [197]. It has been reported that LIM has anti-inflammatory properties, inhibiting lipopolysaccharide (LPS)-induced production of nitric oxide, $\mathrm{PGE}_{2}$ and pro-inflammatory cytokines in RAW 264.7 cells [198]. For this reason, Kaimoto and collaborators [199] investigated the properties of LIM on mouse sensory neurons and heterologously expressed mouse TRP channels in vitro, as well as its nociceptive effects in vivo. The results showed that LIM directly stimulated primary sensory neurons to provoke acute pain through the activation of TRPA1 channel when was topically applied. In addition, its systemic application reduced nociceptive behaviors via $\mathrm{H}_{2} \mathrm{O}_{2}$-induced TRPA1 activation, and this effect is related to the inflammatory pain [199].

\subsection{Nerol}

Nerol (NER) belongs to the family of acyclic monoterpene alcohols and was originally isolated from neroli oil, hence its name. NER is found in many essential oils, such as Agastache mexicana [200] and Citrus aurantium [201]. In previous study, González-Ramírez and collaborators [202] reported the antinociceptive effect of hexane extract from A. mexicana aerial parts in the acetic acid-induced writhing model in rodents. As it has been reported the abundant presence of NER in this species [203], the authors suggested that this monoterpene is partially responsible by antinociceptive and anti-inflammatory activities of A. mexicana [202]. With this background, González-Ramírez and collaborators [203] evaluated the influence of NER in the emergence of pathological markers and hyperalgesia in oxazolone-induced colitis, as well as whether this monoterpene protects against gastric damage induced by ethanol. Pretreatment with NER (30-300 mg/kg, p.o.) significantly alleviated pathological markers (speed up body weight gain, macroscopic damage amelioration, decreased myeloperoxidase activity, reduced inflammatory parameters like disease activity index and intestinal tissue damage) observed in the oxazolone-induced colitis model. It also observed that NER (30 mg/kg) exhibited antinociceptive effect and led to a significant reduction on expression of some pro-inflammatory cytokines, like IL-13 and TNF- $\alpha$. Further, NER was effective in preventing the gastric mucosa against ethanol-induced damage, starting at dose of $10 \mathrm{mg} / \mathrm{kg}$ (p.o.). These findings give evidence of the therapeutic potential of NER for the treatment of important gastrointestinal tract disorders, such as ulcerative colitis and gastric ulcers [203]. 


\subsection{Anethole}

Anethole (ANT), or trans-anethole, is an organic compound frequently used as flavoring substance. It belongs to the family of phenylpropanoids $\left(C_{6}-C_{3}\right)$, a class of aromatic compounds that occurs widely in essential oils [204,205]. ANT is the main constituent of many essential oils [206], such as Illicium verum [207] and Pimpinella anisum [208], and seems to play a key role in the biological effects attributed to these oils. Previous studies have showed that ANT exhibits antioxidant [209], anti-inflammatory [210] and anesthetic [211] activities. With this feedback, Ritter and collaborators [212] examined the effects of ANT on carrageenan-induced acute inflammation and persistent inflammation induced by complete Freund's adjuvant, two pain models of inflammatory origin. Pretreatment with ANT $(125,250$, and $500 \mathrm{mg} / \mathrm{kg}$, p.o.) provoked a noteworthy reduction of mice paw edema at doses of 250 and $500 \mathrm{mg} / \mathrm{kg}$. Similarly, ANT also significantly decreased hypernociceptive response induced by carrageenan at doses of 250 and $500 \mathrm{mg} / \mathrm{kg}$, but was not capable to alter the $\mathrm{PGE}_{2}$-induced mechanical hypernociception. Further, this phenylpropanoid was able to reduce the level of some cytokines (TNF- $\alpha$, IL-1 $\beta$ and IL-17) at doses of 250 and $500 \mathrm{mg} / \mathrm{kg}$, as well as inhibited the myeloperoxidase activity in all tested doses. Taken together, these findings show that ANT exhibits antioedematogenic and antihypernociceptive effects.

In another study, Ritter and collaborators [213] examined the antinociceptive activity of ANT in five experimental models of nociception: acetic acid-induced writhing, formalin test, complete Freund adjuvant-induced pain (CFA), hot-plate test and glutamate test. ANT was able to reduce the total number of writhing in the abdominal constriction model in all assayed doses $(62.5,125,250$ or $500 \mathrm{mg} / \mathrm{kg}$, p.o.). This phenylpropanoid also decreased paw licking times during the second phase of the formalin test only at higher doses (125 and $250 \mathrm{mg} / \mathrm{kg}$ ), but did not affect the nociceptive response in the first phase. Further, pretreatment with ANT significantly reduced paw edema in the glutamate test $(62.5,125$ and $250 \mathrm{mg} / \mathrm{kg})$, and decreased peripheral nociception induced by CFA $(250 \mathrm{mg} / \mathrm{kg})$. On the other hand, ANT, at different doses, did not alter the latency time in the hot plate test, confirming that ANT exhibits no central effect. These data demonstrate that ANT possesses peripheral antinociceptive action and this antinociception occurs, at least in part, by to decrease the synthesis or release of inflammatory mediators [213].

\subsection{Nerolidol}

Nerolidol (NROL), also known as peruviol, is a naturally occurring sesquiterpene alcohol present in various plants with a floral odor. NROL is the allylic isomer of farnesol (FAR) and exists in two geometric isomers, a trans and a cis form, differing only in the geometry about the central double bond [214]. This sesquiterpenoid is found in the volatile oil of many aromatic species, including Canarium schweinfurthii [215] and Baccharis dracunculifolia [216]. With this background, Fonsêca and collaborators [217] investigated the antinociceptive and anti-inflammatory activities of NROL, as well as its possible mechanisms of action, in different experimental mouse models of pain and inflammation. In the acetic acid-induced writhing test, NROL $(200,300$ or $400 \mathrm{mg} / \mathrm{kg}$, p.o.) exhibited a significant antinociceptive effect in all tested doses. In the formalin test, NROL ( 300 or $400 \mathrm{mg} / \mathrm{kg}$ ) was able to reduce nociceptive behavior in both the first phase and the second phase. On the other hand, this sesquiterpene did not increase latency at any of the observed time points in the hot-plate test, suggesting an antinociceptive action on chemical nociception models (acetic acid-induced writhing test and formalin test), but not in the thermal nociception model (hot-plate test). Further, pretreatment with NROL decreased carrageenan-induced paw edema at doses of 200, 300 and $400 \mathrm{mg} / \mathrm{kg}$; and inhibited the production or action of some pro-inflammatory cytokines, like TNF- $\alpha$ and IL-1 $\beta$. Regarding the mechanism of action, the antinociceptive activity of NROL involves the GABAergic system, but not the opioidergic system or ATP-sensitive potassium (KATP) channels [217]. 


\subsection{3. (-)-Carvone}

Carvone (CAR) belongs to the family of monocyclic monoterpene ketones and exists as two optical isomers (different orientations of the isopropenyl group), D- and L-CAR. In general, these individual enantiomers possess specific biological responses, particularly toward olfactory receptors [218]. (-)-CAR is found in relevant quantities in the volatile oils from the Mentha genus, such as the species M. spicata $[219,220]$. This monoterpene is known to have a promising antinociceptive effect, exerting distinct effects on both central and peripheral nervous systems [221]. Until now, few studies were proposed to elucidate the potential mechanisms involved with the antinociceptive action of the (-)-CAR. For this reason, Gonçalves and collaborators [222] investigated the pharmacology of (-)-CAR in dorsal root ganglia (DRG) neurons and TRPV1-expressing HEK293 cells to verify if this compound activates TRPV1 channels. (-)-CAR did not provoke any membrane damage, presenting low cytotoxicity in both neural and epithelial cells. This monoterpene also promoted an elevation of the cytosolic calcium levels in DRG neurons through activation of TRPV1 channels. Further, activity of (-)-CAR on TRPV1 channels was examined in HEK293 cells expressing recombinant human TRPV1 channels, revealing that the increase in the calcium levels occurs in a concentration-dependent manner [222].

\subsection{Farnesol}

Farnesol (FAR) is a natural 15-carbon organic compound that is an acyclic sesquiterpene alcohol. This sesquiterpenoid is commonly found in propolis (a resinous beehive product), citrus fruits and various plant essential oils, such as Tetradenia riparia [223] and Citrus sp. [224]. In study performed by Qamar and Sultana [225], FAR showed protective efficacy against massive lung inflammation, oxidative stress and injuries induced by cigarette smoke toxicants. With this background, the antinociceptive activity of FAR was investigated in two classic behavioral models of analgesia: acetic acid-induced writhing test and the formalin-induced nociception. Pretreatment with FAR (50, 100, and $200 \mathrm{mg} / \mathrm{kg}$, i.p.) caused a noteworthy reduction in the number of contortions in the acetic acid-induced writhing test at all assayed doses. In the formalin test, FAR was capable to inhibit both phases of the pain stimulus at doses of 100 and $200 \mathrm{mg} / \mathrm{kg}$. These results indicate that FAR possesses antinociceptive activity and this effect was similar to that found with centrally-acting analgesic drugs, like morphine and tramadol [226].

\subsection{5. $\beta$-Caryophyllene}

$\beta$-Caryophyllene ( $\beta$-CARY), a natural bicyclic sesquiterpene, is the main volatile constituent found in the essential oil of many common spices and food plants, such as Cinnamomum spp. [227], Origanum vulgare [228] and Piper nigrum [229]. In nature, is found three isomers, named (E)- $\beta$-CARY, (Z)- $\beta$-CARY (or isocaryophyllene), and $\alpha$-humulene (formerly $\alpha$-caryophyllene), a ring-opened isomer [230]. Further, $\beta$-CARY is known to be the main constituent of Cannabis sativa essential oil [231] as well as to possess antiarthritic effect [232] and noteworthy anti-inflammatory activity against carrageenan- and $\mathrm{PGE}_{1}$-induced edema in rats [233]. With this background, [234] examined the contribution of opioid and peripheral cannabinoid (CB) systems in the antinociceptive action produced by $\beta$-CARY as well as its action in combination with the opioid agonist morphine. $\beta$-CARY [9.0 $\mu \mathrm{g} / \mathrm{paw}$ or $18.0 \mu \mathrm{g} / \mathrm{paw}$, intraplantar (i.pl)] was able to attenuate the capsaicin-induced nociceptive behavioral response and in a dose-dependent manner. Further, $\beta$-CARY-induced antinociception was mediated by peripheral $\mathrm{CB}_{2}$ receptor activation, which stimulates the local release of $\beta$-endorphin, an endogenous opioid, from keratinocytes. Finally, it was also observed a synergistic antinociceptive interaction between $\beta$-CARY and morphine, fact that may be an interesting therapeutic alternative to minimize risk of undesirable side-effects caused by this opioid analgesic [234]. 


\subsection{6. $\alpha, \beta$-Epoxy-Carvone}

$\alpha, \beta$-Epoxy-carvone (ECAR) is a naturally occurring monocyclic monoterpene containing an epoxy group instead of the $\alpha, \beta$-unsaturated ketone group present in CAR [235]. This monoterpene is present in the essential oils of various aromatic species such as Kaempferia galangal [236] and Carum carvi [237], but can also be obtained by organic synthesis [238]. ECAR exhibits depressor effect on CNS [180] and antimicrobial [239] and anticonvulsant activities [240]. In 2013, Da Rocha and collaborators [241] investigated the antinociceptive and anti-inflammatory effects of this monoterpenoid in four experimental mice models: acetic acid-induced writhing, formalin induced nociception, hot-plate test and peritoneal permeability induced by acetic acid. ECAR promoted a significant antinociceptive effect in the acetic acid-induced abdominal writhing test at doses of 100, 200 or $300 \mathrm{mg} / \mathrm{kg}$ (i.p.). In the formalin test, ECAR inhibited nociception in both the first phase $(300 \mathrm{mg} / \mathrm{kg})$ and second phase (200 and $300 \mathrm{mg} / \mathrm{kg}$ ). In the hot-plate test, pretreatment with ECAR caused a significant latency prolongation at $30 \mathrm{~min}(100,200$ and $300 \mathrm{mg} / \mathrm{kg}), 60$ and $120 \mathrm{~min}(300 \mathrm{mg} / \mathrm{kg})$; and this effect was reversed by naloxone. Finally, ECAR was capable to inhibit the acetic acid-induced peritoneal capillary permeability at dose of $300 \mathrm{mg} / \mathrm{kg}$ [241].

\section{Materials and Methods}

The compounds presented in this review were selected based on the effects shown in specific animal models for evaluation of the antinociceptive activity. Table 1 summarizes the essential oil constituents with antinociceptive activity. The search was conducted in the scientific database PubMed, focusing on works published during the last six years (January 2011 to December 2016). The data were selected using the following terms: "essential oils", "monoterpene," and "phenylpropanoids" refining with "analgesic" or "antinociceptive".

Table 1. Essential oils constituents with antinociceptive activity.

\begin{tabular}{|c|c|c|c|c|}
\hline Compound & Experimental Protocol & $\begin{array}{l}\text { Antinociceptive Activity } \\
\text { and/or Mechanism }\end{array}$ & $\begin{array}{l}\text { Animal Tested } \\
\text { and/or Cell Line }\end{array}$ & Reference \\
\hline \multirow{4}{*}{$p$-Cymene } & $\begin{array}{l}\text { Formalin, capsaicin and } \\
\text { glutamate-induced } \\
\text { orofacial nociception }\end{array}$ & Decreased rubbing behavior & Male Swiss mice & [19] \\
\hline & $\begin{array}{l}\text { Acetic acid-induced } \\
\text { writhing, formalin and } \\
\text { hot plate tests } \\
\text { CG-induced inflammation }\end{array}$ & $\begin{array}{l}\text { Reduced writhes, and } \\
\text { liking time } \\
\text { Increased latency time of } \\
\text { liking and jumping behavior } \\
\text { Reduced leukocyte } \\
\text { migration }\end{array}$ & Male Swiss mice & [20] \\
\hline & $\begin{array}{l}\text { Tail flick test } \\
\text { CG, TNF- } \alpha \text {, PGE2 and } \\
\text { dopamine-induced } \\
\text { hypernociception } \\
\text { CG-induced pleurisy } \\
\text { LPS-induced NO secretion } \\
\text { Fos protein } \\
\text { immunofluorescence }\end{array}$ & $\begin{array}{l}\text { Increased latency } \\
\text { time response } \\
\text { Decreased mechanical } \\
\text { hypernociception } \\
\text { Reduced leukocyte and } \\
\text { neutrophils migration and } \\
\text { TNF- } \alpha \text { level } \\
\text { Reduced NO production } \\
\text { Increased c-Fos } \\
\text { immunoreaction }\end{array}$ & $\begin{array}{c}\text { Male Swiss mice } \\
\text { Macrophage } \\
\text { Periaqueductal grey } \\
\text { neurons }\end{array}$ & [25] \\
\hline & $\begin{array}{l}\text { Acetic acid-induced } \\
\text { writhing and formalin tests }\end{array}$ & $\begin{array}{l}\text { Reduced writhes, and } \\
\text { liking time }\end{array}$ & Male Swiss mice & [31] \\
\hline
\end{tabular}


Table 1. Cont.

\begin{tabular}{|c|c|c|c|c|}
\hline Compound & Experimental Protocol & $\begin{array}{l}\text { Antinociceptive Activity } \\
\text { and/or Mechanism }\end{array}$ & $\begin{array}{l}\text { Animal Tested } \\
\text { and/or Cell Line }\end{array}$ & Reference \\
\hline & $\begin{array}{l}\text { Acetic acid-induced } \\
\text { writhing test } \\
\text { Formalin test } \\
\text { Hot plate test } \\
\text { Peritoneal permeability } \\
\text { induced by acetic acid }\end{array}$ & $\begin{array}{l}\text { Reduced the number of } \\
\text { abdominal contortions } \\
\text { Inhibited nociception in both } \\
\text { the first phase and } \\
\text { second phase } \\
\text { Caused a significant } \\
\text { latency prolongation } \\
\text { Inhibited the acetic } \\
\text { acid-induced peritoneal } \\
\text { capillary permeability }\end{array}$ & Male albino Swiss mice & [241] \\
\hline & $\begin{array}{l}\text { Acetic acid-induced } \\
\text { writhing, formalin and hot } \\
\text { plate tests }\end{array}$ & $\begin{array}{l}\text { Reduced writhes, and } \\
\text { paw-liking time } \\
\text { Increased latency } \\
\text { time response }\end{array}$ & Male Swiss mice & [40] \\
\hline & $\begin{array}{l}\text { CG, TNF- } \alpha, \text { PGE2 and } \\
\text { dopamine-induced } \\
\text { hypernociception } \\
\text { CG-induced paw edema } \\
\text { CG-induced pleurisy } \\
\text { LPS-induced nitrite secretion }\end{array}$ & $\begin{array}{l}\text { Decreased mechanical } \\
\text { hypernociception } \\
\text { Decreased edema volume } \\
\text { Reduced leukocyte } \\
\text { migration and TNF- } \alpha \text { level } \\
\text { Reduced nitrite production }\end{array}$ & $\begin{array}{l}\text { Male Swiss mice } \\
\text { Macrophage }\end{array}$ & [42] \\
\hline & $\begin{array}{l}\text { Formalin, capsaicin and } \\
\text { glutamate-induced } \\
\text { orofacial nociception }\end{array}$ & $\begin{array}{l}\text { Reduced face-rubbing } \\
\text { behavior }\end{array}$ & Male Swiss mice & [43] \\
\hline & $\begin{array}{l}\text { Whole-cell voltage-clamp } \\
\text { recordings }\end{array}$ & $\begin{array}{l}\text { Increased secretion } \\
\text { of L-glutamate } \\
\text { Membrane } \\
\text { hyperpolarization }\end{array}$ & Rat spinal cord & [44] \\
\hline & $\begin{array}{l}\text { Whole-cell voltage-clamp } \\
\text { recordings } \\
\text { Intracellular recordings }\end{array}$ & $\begin{array}{l}\text { Inhibition of excitability } \\
\text { Generation of } \\
\text { action potentials }\end{array}$ & $\begin{array}{l}\text { Male and female } \\
\text { Wistar rat sciatic nerve } \\
\text { and dorsal root ganglia }\end{array}$ & [47] \\
\hline & $\begin{array}{l}\text { von Frey test } \\
\text { (electronic version) }\end{array}$ & $\begin{array}{l}\text { Reduced mechanical } \\
\text { allodynia }\end{array}$ & $\begin{array}{l}\text { Male ddY-strain mice } \\
\text { (sciatic nerve ligation) }\end{array}$ & [56] \\
\hline & Formalin test & $\begin{array}{l}\text { Reduced licking and } \\
\text { biting behavior }\end{array}$ & Male ddY-strain mice & [62] \\
\hline & $\begin{array}{l}\text { Xylene-induced ear edema } \\
\text { and formalin-induced hind } \\
\text { paw edema } \\
\text { COX-2 expression and } \\
\text { inflammatory infiltrates } \\
\text { immunohistochemistry }\end{array}$ & $\begin{array}{l}\text { Reduced edema volume } \\
\text { Decreased COX-2 expression } \\
\text { and inflammatory infiltrates }\end{array}$ & Male Kunming mice & [64] \\
\hline & $\begin{array}{l}\text { Formalin and hot plate tests } \\
\text { c-Fos immunohistochemistry }\end{array}$ & $\begin{array}{l}\text { Increased latency time of } \\
\text { hindpaw withdrawl } \\
\text { Increased c-Fos expression } \\
\text { in hypothalamic } \\
\text { orexin neurons }\end{array}$ & $\begin{array}{l}\text { Wild type mice } \\
(\text { C57BL/6) } \\
\text { Orexin neuron- } \\
\text { ablated mice } \\
\text { Orexin peptide- } \\
\text { deficient mice }\end{array}$ & [65] \\
\hline
\end{tabular}


Table 1. Cont.

\begin{tabular}{|c|c|c|c|c|}
\hline \multirow[t]{2}{*}{ Compound } & Experimental Protocol & $\begin{array}{l}\text { Antinociceptive Activity } \\
\text { and/or Mechanism }\end{array}$ & $\begin{array}{l}\text { Animal Tested } \\
\text { and/or Cell Line }\end{array}$ & Reference \\
\hline & $\begin{array}{l}\text { Paclitaxel-induced acute } \\
\text { pain (von Frey filaments) }\end{array}$ & $\begin{array}{l}\text { Inhibiton of mechanical } \\
\text { allodynia and } \\
\text { hypernociception }\end{array}$ & Male ddY-strain mice & [48] \\
\hline \multirow{3}{*}{ (-)-Linalool } & $\begin{array}{l}\text { Formalin, capsaicin and } \\
\text { glutamate-induced } \\
\text { orofacial nociception } \\
\text { Field potential recordings }\end{array}$ & $\begin{array}{l}\text { Reduced face- } \\
\text { rubbing behavior } \\
\text { Inhibition of field potentials }\end{array}$ & $\begin{array}{l}\text { Male Swiss mice } \\
\text { Hippocampal } \\
\text { dentate gyrus }\end{array}$ & [53] \\
\hline & $\begin{array}{l}\text { Acetic acid-induced } \\
\text { writhing, formalin and hot } \\
\text { plate tests } \\
\text { CG-induced peritonitis }\end{array}$ & $\begin{array}{l}\text { Reduced writhes, and } \\
\text { paw-liking time } \\
\text { Increased latency } \\
\text { time response } \\
\text { Inhibition of leukocyte } \\
\text { migration and TNF- } \alpha \text { level }\end{array}$ & Male Swiss mice & [67] \\
\hline & $\begin{array}{l}\text { Chronic noninflammatory } \\
\text { muscle pain model } \\
\text { c-Fos protein } \\
\text { immunofluorescence }\end{array}$ & $\begin{array}{l}\text { Inhibition of mechanical } \\
\text { hypernociception } \\
\text { Neuron activation }\end{array}$ & Male Swiss mice & [69] \\
\hline \multirow{4}{*}{ Eugenol } & $\begin{array}{l}\text { Acetic acid-induced } \\
\text { writhing and formalin tests } \\
\text { Substance P and } \\
\text { glutamate-induced } \\
\text { nociceptive behavior }\end{array}$ & $\begin{array}{l}\text { Reduced writhes, and } \\
\text { paw-liking/biting behavior } \\
\text { Reduced nociceptive } \\
\text { response }\end{array}$ & Male ICR mice & [73] \\
\hline & Lingual irritation method & $\begin{array}{l}\text { Oral irritation } \\
\text { desensitization } \\
\text { Increased innocuous } \\
\text { warmth and noxious } \\
\text { heat sensation }\end{array}$ & Human subjects & [83] \\
\hline & $\begin{array}{l}\text { Acetic acid-induced } \\
\text { writhing test and } \\
\text { glutamate-induced } \\
\text { nociception } \\
\text { Glutamate, AMPA, kainate, } \\
\text { substance P and } \\
\text { TNF- } \alpha \text {-induced pain }\end{array}$ & $\begin{array}{l}\text { Reduced writhes } \\
\text { Reduced nociception } \\
\text { Inhibition of biting behavior }\end{array}$ & Male Swiss mice & [71] \\
\hline & $\begin{array}{l}\text { Monoiodoacatate-induced } \\
\text { osteoarthritis } \\
\text { von Frey filaments method } \\
\text { Spinal pain-related } \\
\text { peptide analysis }\end{array}$ & $\begin{array}{l}\text { Altered gait parameters } \\
\text { Reduced mechanical } \\
\text { allodynia } \\
\text { Reduced expression of } \\
\text { substance P and calcitonin } \\
\text { gene-related peptide } \\
\text { Increased dynorphin level }\end{array}$ & $\begin{array}{l}\text { Sprague Dawley rats } \\
\text { Spinal cord samples }\end{array}$ & [80] \\
\hline \multirow{2}{*}{$\underbrace{\mathrm{OH}}_{\text {ugenol }}$} & $\begin{array}{l}\text { Sciatic nerve constriction } \\
\text { von Frey and hot plate tests } \\
\text { Biochemical assay }\end{array}$ & $\begin{array}{l}\text { Inhibition of mechanical } \\
\text { hypernociception } \\
\text { Increased latency } \\
\text { time response } \\
\text { Reduced IL-1 } \beta \text { level }\end{array}$ & $\begin{array}{l}\text { Male C57BL/6J mice } \\
\text { Sciatic nerve }\end{array}$ & [79] \\
\hline & & & & \\
\hline
\end{tabular}


Table 1. Cont.

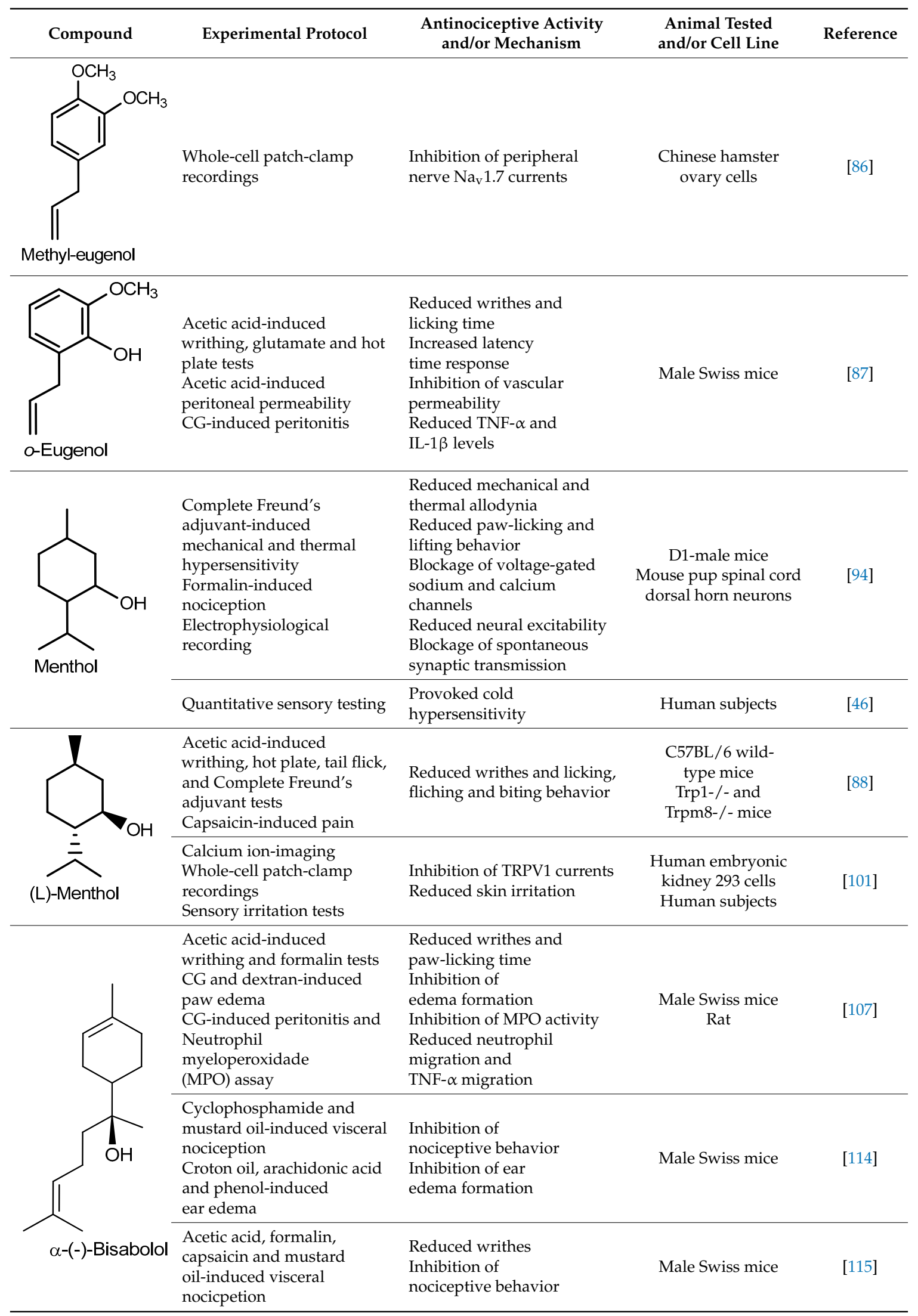


Table 1. Cont.

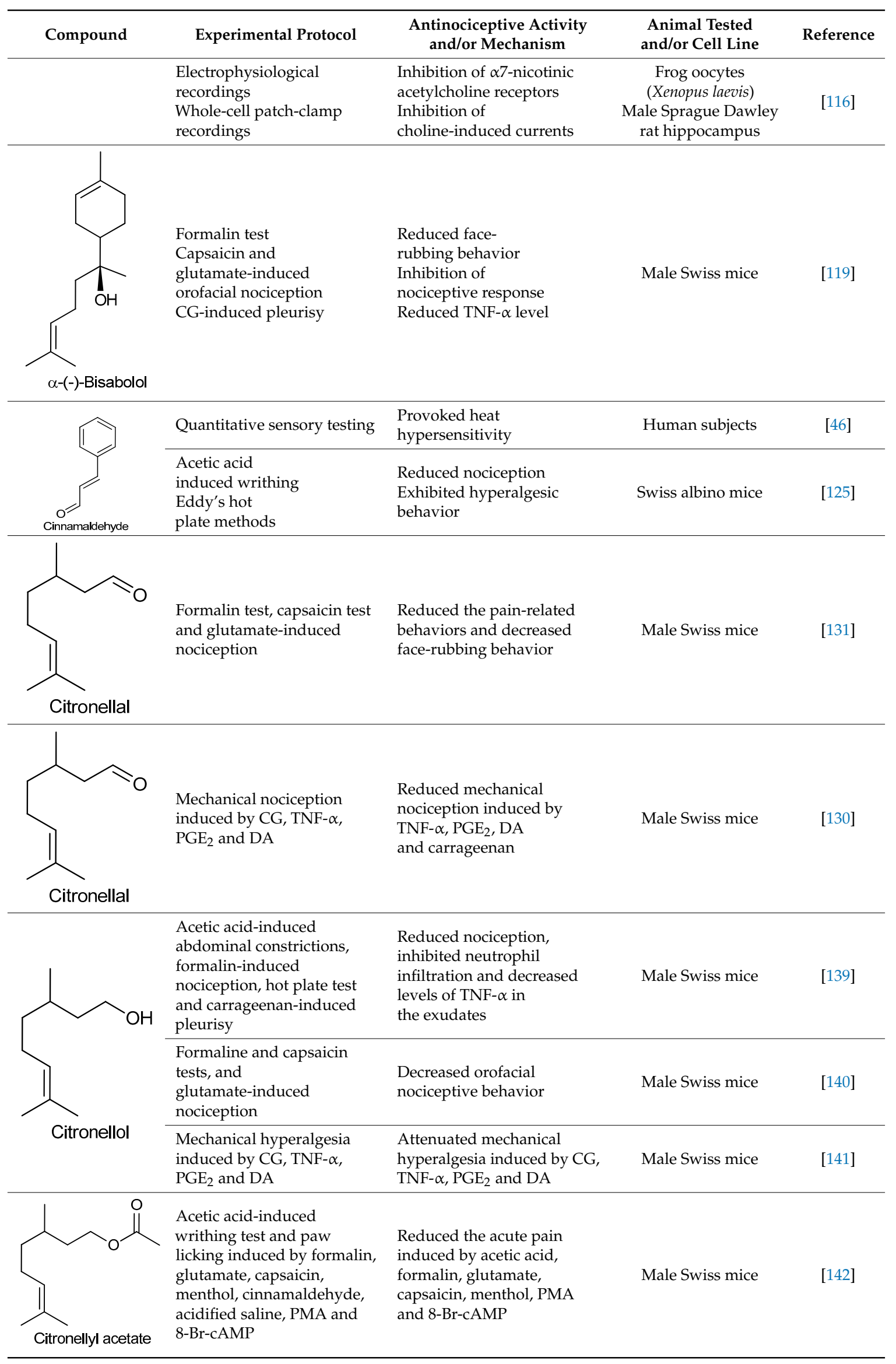


Table 1. Cont.

\begin{tabular}{|c|c|c|c|c|}
\hline Compound & Experimental Protocol & $\begin{array}{l}\text { Antinociceptive Activity } \\
\text { and/or Mechanism }\end{array}$ & $\begin{array}{l}\text { Animal Tested } \\
\text { and/or Cell Line }\end{array}$ & Reference \\
\hline \multirow{2}{*}{-Phellandrene } & $\begin{array}{l}\text { Acetic acid-induced } \\
\text { abdominal writhing, } \\
\text { formalin, capsaicin and } \\
\text { glutamate tests } \\
\text { Mechanical } \\
\text { hypernociception and } \\
\text { carrageenan-induced } \\
\text { inflammatory } \\
\text { hypernociception }\end{array}$ & $\begin{array}{l}\text { Decreased the } \\
\text { nociceptive response } \\
\text { Reduced the } \\
\text { hypernociception index }\end{array}$ & Male Swiss mice & [156] \\
\hline & $\begin{array}{l}\text { Acetic acid writhing reflex, } \\
\text { hot plate test, and formalin-, } \\
\text { capsaicin- and } \\
\text { glutamate-induced } \\
\text { nociception }\end{array}$ & $\begin{array}{l}\text { Showed central analgesic } \\
\text { properties and reduced } \\
\text { nociceptive response } \\
\text { induced by acetic acid, } \\
\text { formalin, glutamate } \\
\text { and capsaicin }\end{array}$ & Male Swiss mice & [160] \\
\hline \multirow{3}{*}{$\overbrace{\substack{\mathrm{OH} \\
\text { Vanillin }}}$} & Eddy's hot plate method & $\begin{array}{l}\text { Increased the latency period, } \\
\text { suggesting a potential } \\
\text { central analgesic activity }\end{array}$ & Adult Wistar rats & [166] \\
\hline & $\begin{array}{l}\text { Carrageenan induced } \\
\text { paw edema }\end{array}$ & Decreased the paw volume & Adult Wistar rats & [167] \\
\hline & $\begin{array}{l}\text { Tail flick method and } \\
\text { carrageenan induced rat } \\
\text { paw edema }\end{array}$ & $\begin{array}{l}\text { Showed antinociceptive } \\
\text { effect and decreased the } \\
\text { paw volume }\end{array}$ & Adult Wistar rats & [168] \\
\hline \multirow{3}{*}{ (+)-Borneol } & $\begin{array}{l}\text { Acetic acid-induced } \\
\text { abdominal writhings, } \\
\text { formalin-induced } \\
\text { nociception, hot plate test, } \\
\text { grip strength test and } \\
\text { carrageenan-induced } \\
\text { peritonitis }\end{array}$ & $\begin{array}{l}\text { Reduced the antinociceptive } \\
\text { behavior, increased the } \\
\text { latency time and decreased } \\
\text { the leukocyte migration to } \\
\text { the peritoneal cavity }\end{array}$ & Male Swiss mice & [175] \\
\hline & $\begin{array}{l}\text { Segmental spinal nerve } \\
\text { ligation-induced } \\
\text { neuropathic pain and } \\
\text { complete Freund's } \\
\text { adjuvant-induced } \\
\text { inflammatory pain }\end{array}$ & $\begin{array}{l}\text { Attenuated mechanical } \\
\text { hyperalgesia through } \\
\text { activation spinal GABAergic } \\
\text { transmission in the } \\
\text { spinal cord }\end{array}$ & Male adult ICR mice & {$[176]$} \\
\hline & $\begin{array}{l}\text { Acetic acid-induced } \\
\text { writhing } \\
\text { Paw licking induced by } \\
\text { formalin, glutamate } \\
\text { and capsaicin } \\
\text { Hot-plate test } \\
\text { Paw edema induced by } \\
\text { compound } 48 / 80 \text {, serotonin, } \\
\text { histamine or PGE } 2 \\
\text { Carrageenan-induced } \\
\text { peritonitis }\end{array}$ & $\begin{array}{l}\text { Inhibited acetic } \\
\text { acid-induced nociception } \\
\text { Decreased time of licking } \\
\text { the paw } \\
\text { Did not change the latency } \\
\text { reaction time } \\
\text { Reduced the paw edema and } \\
\text { Reduced the cytokine levels }\end{array}$ & Male Swiss mice & [183] \\
\hline & $\begin{array}{l}\text { Formalin test and hot } \\
\text { plate test }\end{array}$ & $\begin{array}{l}\text { Inhibited both phases of the } \\
\text { formalin test and } \\
\text { augmented the latency } \\
\text { reaction time in hot plate }\end{array}$ & Male Swiss mice & [3] \\
\hline
\end{tabular}


Table 1. Cont.

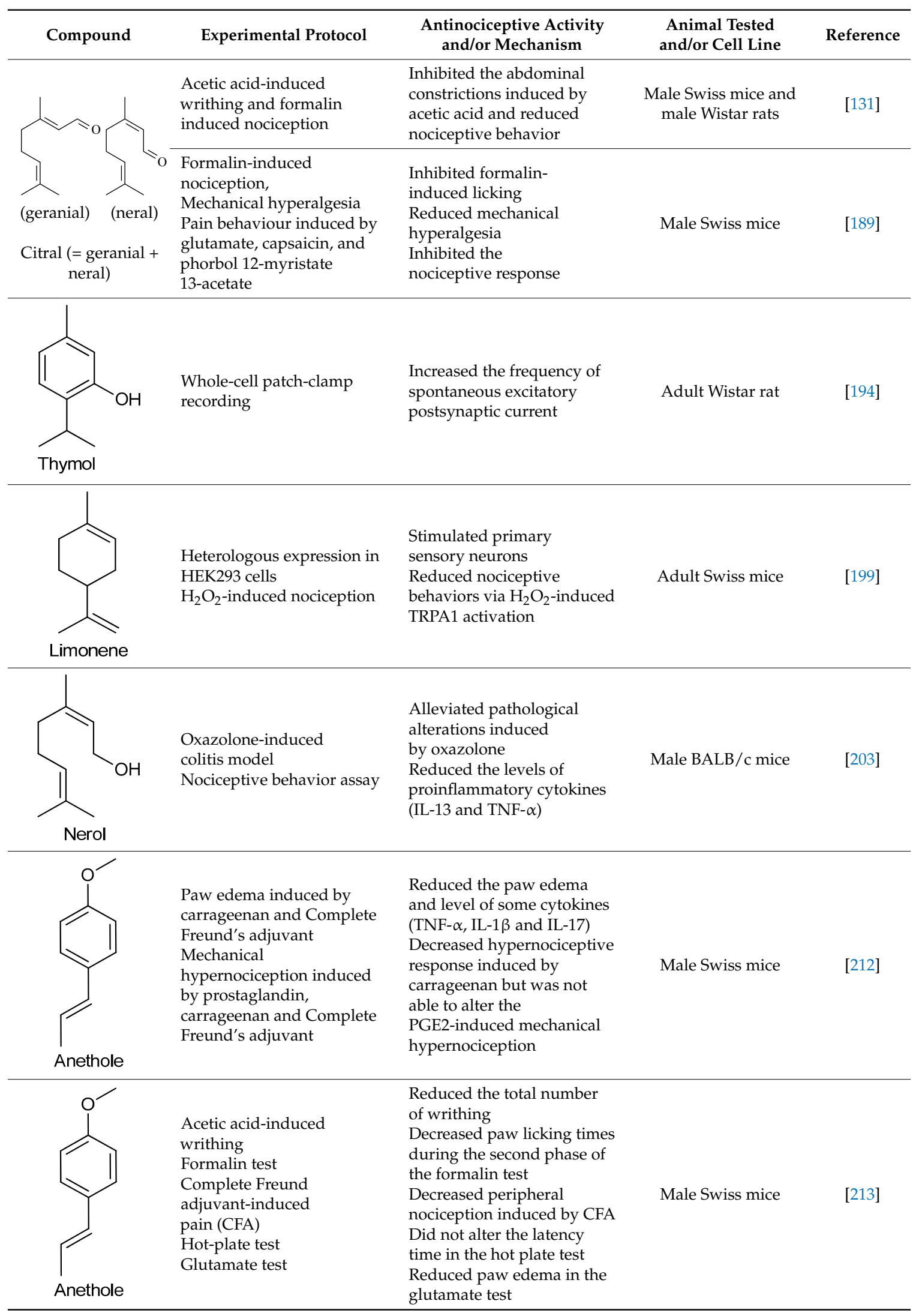


Table 1. Cont.

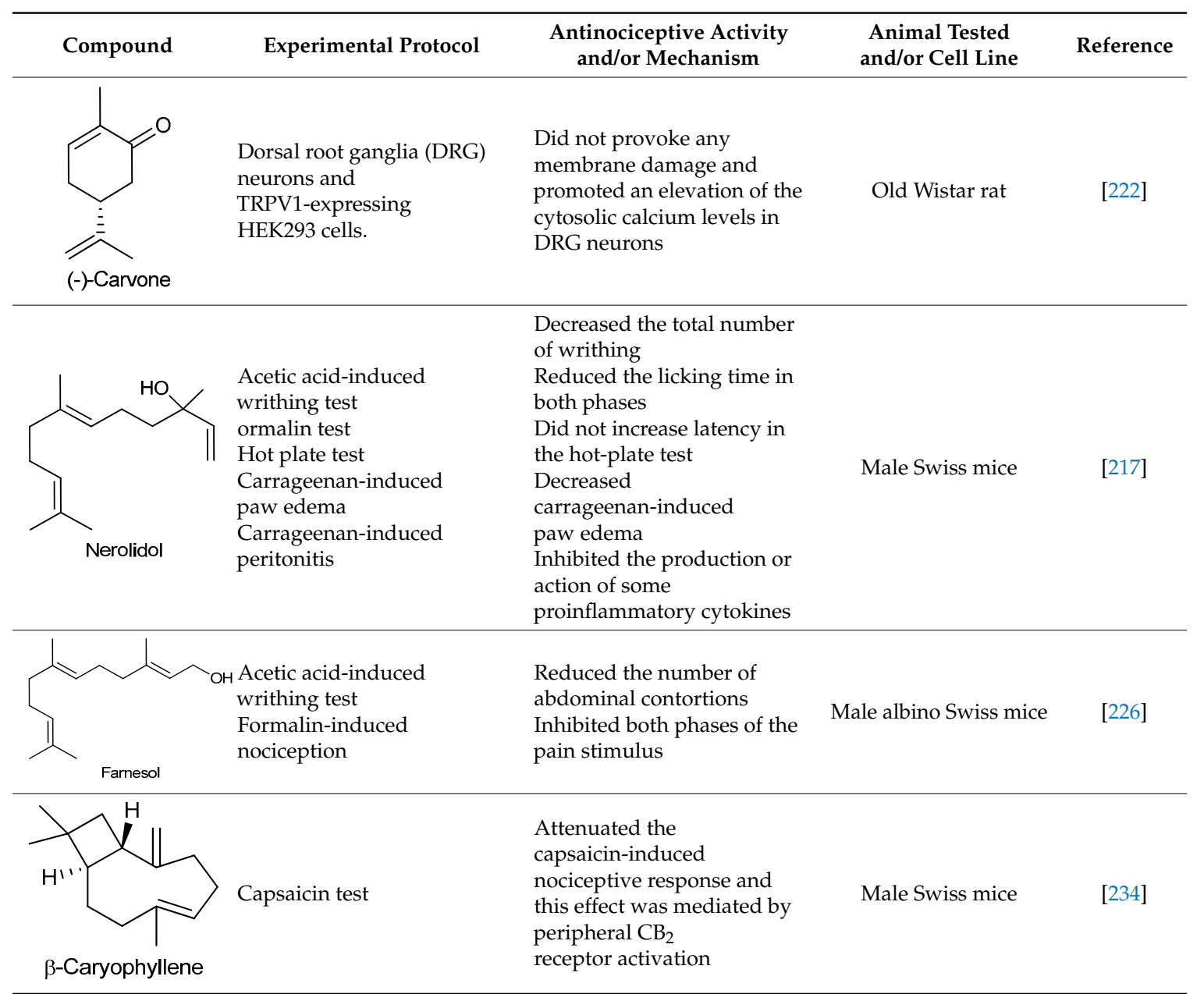

CG: carrageenan; TNF- $\alpha$ : tumor necrosis factor $\alpha$; $\mathrm{PGE}_{2}$ : prostaglandin $\mathrm{E}$ type 2; LPS: lipopolysaccharide; NO: nitric oxide; COX-2: ciclo oxigenase type 2; ICR: Institute of Cancer Research; AMPA: adenosine $3^{\prime}, 5^{\prime}$-cyclic monophosphate; IL: interleucin; TRPV: transient receptor potential vanilloid; DA: dopamine; PMA: phorbol myristate acetate; 8-Br-cAMP: 8-bromo-adenosine $3^{\prime}, 5^{\prime}$-cyclic monophosphate; GABAergic: $\gamma$-aminobutyric acid; TRPA: transient receptor potential ankyrin; $\mathrm{CB}_{2}$ : cannabinoid receptor type 2 .

\section{Conclusions}

The increasing number of studies on the antinociceptive activity of essential oil constituents shows the therapeutic potential of this chemical class. Effective in various animal models of pain and acting via different mechanisms of action, these compounds are interesting molecules for studies in clinical approaches. Despite the small amount of various antinociceptive constituents in the essential oils, it is possible, using low cost reactions, to easily synthesize some of these compounds, such as monoterpenes $\alpha$, $\beta$-epoxy-carvone [180] and hydroxydihydrocarvone [242,243], which were obtained via organic synthesis. The use of these bioactive constituents as prototypes to synthesize analogous compounds is another interesting way forward in the development of new analgesic drugs. It is also necessary to investigate the toxicological aspect of essential oils. Only a few publications have shown possible toxicological effects of essential oils to humans. For example, constituents as linalool, whose antinociceptive activity in animals is well established [244-247], have been the subject of few toxicological studies in humans [248]. The standardization of the experimental protocols is also essential to establish better doses and routes of administration. In this way, it is possible to make a more appropriate comparative analysis between the oils. In addition, the investigation of the chemical composition of essential oils is important to complement the pharmacological and toxicological approach. The present review makes it possible to conclude that the structural diversity of 
the bioactive constituents does not allow the establishment of a chemical characteristic responsible for antinociceptive action. Advanced studies on the mechanisms of action of these constituents, together with the computational medicinal chemistry approach, may be a more efficient way to understand the chemical requirement for this pharmacological activity.

Acknowledgments: This work was supported by the Brazilian agencies: Conselho Nacional de Desenvolvimento Científico e Tecnológico (CNPq) and Coordenação de Aperfeiçoamento de Pessoal de Nível Superior (CAPES).

Author Contributions: Rita de Cássia da Silveira e Sá and Tamires Cardoso Lima wrote the pharmacological part of the review. Flávio Rogério da Nóbrega surveyed the data. Damião Pergentino de Sousa was responsible for the analysis of these data, wrote the chemical content, revised and planned the study. Anna Emmanuela Medeiros de Brito was responsible for formatting the manuscript.

Conflicts of Interest: The authors declare no conflict of interest.

\section{References}

1. Franco, M.R.B. Aroma e Sabor de Alimentos: Temas Atuais; Varela Editora e Livraria Ltda: São Paulo, Brazil, 2003.

2. Marchese, A.; Barbieri, R.; Coppo, E.; Orhan, I.E.; Daglia, M.; Nabavi, S.F.; Izadi, M.; Abdollahi, M.; Nabavi, S.M.; Ajami, M. Antimicrobial activity of eugenol and essential oils containing eugenol: A mechanistic viewpoint. Crit. Rev. Microbiol. 2017, 43, 668-689. [CrossRef] [PubMed]

3. De Sousa, D.P.; Nóbrega, F.F.F.; Lima, M.R.V.; Almeida, R.N. Pharmacological Activity of (R)-(+)-pulegone, a chemical constituent of essential oils. Z. Naturforsch. 2011, 66, 353-359. [CrossRef]

4. De Sousa, D.P. Analgesic-like activity of essential oils constituents. Molecules 2011, 16, 2233-2252. [CrossRef] [PubMed]

5. Sarmento-Neto, J.F.; Do Nascimento, L.G.; Felipe, C.F.; de Sousa, D.P. Analgesic Potential of Essential Oils. Molecules 2015, 21, 20. [CrossRef] [PubMed]

6. De Almeida, R.N.; Agra, M.F.; Maior, F.N.; de Sousa, D.P. Essential oils and their constituents: Anticonvulsant activity. Molecules 2011, 16, 2726-2742. [CrossRef] [PubMed]

7. De Cássia da Silveira e Sá, R.; Andrade, L.N.; de Sousa, D.P. A review on anti-inflammatory activity of monoterpenes. Molecules 2013, 18, 1227-1254. [CrossRef] [PubMed]

8. De Cássia da Silveira e Sá, R.; Andrade, L.N.; de Sousa, D.P. Sesquiterpenes from Essential Oils and Anti-Inflammatory Activity. Nat. Prod. Commun. 2015, 10, 1767-1774.

9. De Cássia da Silveira e Sá, R.; Andrade, L.N.; Dos Reis Barreto de Oliveira, R.; de Sousa, D.P. A review on anti-inflammatory activity of phenylpropanoids found in essential oils. Molecules 2014, 19, 1459-1480. [CrossRef] [PubMed]

10. Carvalho, A.A.; Andrade, L.N.; de Sousa, E.B.; de Sousa, D.P. Antitumor phenylpropanoids found in essential oils. Biomed. Res. Int. 2015, 2015, 392674. [CrossRef] [PubMed]

11. De Sousa, D.P. Bioactive Essential Oils and Cancer; Springer International Publishing: New York, NY, USA, 2015.

12. Sobral, M.V.; Xavier, A.L.; Lima, T.C.; de Sousa, D.P. Antitumor activity of monoterpenes found in essential oils. Sci. World J. 2014, 2014, 953451. [CrossRef] [PubMed]

13. De Sousa, D.P.; de Almeida Soares Hocayen, P.; Andrade, L.N.; Andreatini, R.A. Systematic Review of the Anxiolytic-Like Effects of Essential Oils in Animal Models. Molecules 2015, 20, 18620-18660. [CrossRef] [PubMed]

14. Oliveira, F.A.; Andrade, L.N.; de Sousa, E.B.; de Sousa, D.P. Anti-ulcer activity of essential oil constituents. Molecules 2014, 19, 5717-5747. [CrossRef] [PubMed]

15. IASPPainTerminology. Available online: http://www.iasppain.org/AM/Template.cfm?Section=Pain_ Definitions\&Template $=/$ CM/HTMLDisplay.cfm\&ContentID=1728\#Pain (accessed on 8 December 2010).

16. Oliveira, F.A.; Costa, C.L.S.; Chaves, M.H.; Almeida, F.R.C.; Cavalcante, I.J.M.; Lima, A.F.; Lima-Júnior, R.C.P.; Silva, R.M.; Campos, A.R.; Santos, F.A.; et al. Attenuation of capsaicin-induced acute and visceral nociceptive pain by $\alpha$ - and $\beta$-amyrin, a triterpene mixture isolated from Protium heptaphyllum resin in mice. Life Sci. 2005, 77, 2942-2952. [CrossRef] [PubMed]

17. Bispo, M.D.; Mourão, R.H.V.; Franzotti, E.M.; Bomfim, K.B.R.; Arrigoni-Blank, M.F.; Moreno, M.P.N.; Marchioro, M.; Antoniolli, A.R. Antinociceptive and antiedematogenic effects of the aqueous extract of Hyptis pectinata leaves in experimental animals. J. Etnopharmacol. 2001, 76, 81-86. [CrossRef] 
18. Quintans, J.S.S.; Menezes, P.P.; Santos, M.R.V.; Bonjardim, L.R.; Almeida, J.R.G.S.; Gelain, D.P.; Araújo, A.A.S.; Quintans-Júnior, L.J. Improvement of p-cymene antinociceptive and anti-inflammatory effects by inclusion in $\beta$-cyclodextrin. Phytomedicine 2013, 20, 436-440. [CrossRef] [PubMed]

19. Santana, M.F.; Quintans-Júnior, L.J.; Cavalcanti, S.C.H.; Oliveira, M.G.B.; Guimarães, A.G.; Cunha, E.S.; Melo, M.S.; Santos, M.R.V.; Araújo, A.A.S.; Bonjardim, L.R. $p$-Cymene reduces orofacial nociceptive response in mice. Braz. J. Pharmacogn. 2011, 21, 1138-1143. [CrossRef]

20. Bonjardim, L.R.; Cunha, E.S.; Guimaraes, A.G.; Santana, M.F.; Oliveira, M.G.B.; Serafini, M.R.; Araujo, A.A.S.; Antoniolli, A.R.; Cavalcanti, S.C.H.; Santos, M.R.V.; et al. Evaluation of the Anti-Infl ammatory and Antinociceptive Properties of $p$-Cymene in Mice. Z. Naturforsch. 2012, 67, 15-21. [CrossRef]

21. Ferreira, S.H.; Lorenzetti, B.B.; Poole, S. Bradykinin initiates cytokine-mediated inflammatory hyperalgesia. Br. J. Pharmacol. 1993, 110, 1227-1231. [CrossRef] [PubMed]

22. Cunha, T.M.; Verri, W.A., Jr.; Silva, J.S.; Poole, S.; Cunha, F.Q.; Ferreira, S.H. A cascade of cytokines mediates mechanical inflammatory hypernociception in mice. Proc. Natl. Acad. Sci. USA 2005, 102, 1755-1760. [CrossRef] [PubMed]

23. Dray, A. Inflammatory mediators of pain. Br. J. Anaesth. 1995, 75, 125-131. [CrossRef] [PubMed]

24. Cunha, F.Q.; Poole, S.; Lorenzetti, B.B.; Ferreira, S.H. The pivotal role of tumour necrosis factor $\alpha$ in the development of inflammatory hyperalgesia. Br. J. Pharmacol. 1992, 107, 660-664. [CrossRef] [PubMed]

25. Santana, M.F.; Guimarães, A.G.; Chaves, D.O.; Silva, J.C.; Bonjardim, L.R.; Júnior, W.L.; Ferro, J.N.S.; Barreto, E.O.; Santos, F.E.; Soares, M.B.P.; et al. The anti-hyperalgesic and anti-inflammatory profiles of p-cymene: Evidence for the involvement of opioid system and cytokines. Pharm. Biol. 2015, 53, 1583-1590. [CrossRef] [PubMed]

26. Conti, P.; Reale, M.; Fiore, S.; Cancelli, A.; Angeletti, P.U.; Dinarello, C.A. Recombinant interleukin 1 and tumor necrosis factor acting in synergy to release thromboxane, 6-KETO-PGF1 and PGE2 by human neutrophils. Scand. J. Rheumatol. Suppl. 1998, 75, 318-324.

27. Kassama, T.; Miwa, Y.; Isozaki, T.; Odai, T.; Adachi, M.; Kunkel, S.L. Neutrophil-derived cytokines potential therapeutic targets in inflammation. Curr. Drug Targets Inflamm. Allergy 2005, 4, 273-279. [CrossRef]

28. Yang, E.J.; Yim, E.Y.; Song, G.; Kim, G.O.; Hyun, C.G. Inhibition of nitric oxide production in lipopolysaccharide-activated RAW 264.7 macrophages by Jeju plant extracts. Interdiscip. Toxicol. 2009, 2, 245-249. [CrossRef] [PubMed]

29. Tao, F.; Tao, Y.X.; Zhao, C.; Doré, S.; Liaw, W.J.; Raja, S.N.; Johns, R.A. Differential roles of neuronal and endothelial nitric oxide synthases during carrageenan-induced inflammatory hyperalgesia. Neuroscience 2004, 128, 421-430. [CrossRef] [PubMed]

30. Ossipov, M.H.; Dussor, G.O.; Porreca, F. Central modulation of pain. J. Clin. Investig. 2010, 120, 3779-3787. [CrossRef] [PubMed]

31. Quintans-Júnior, L.J.; Moreira, J.C.F.; Pasquali, M.A.B.; Rabie, S.M.S.; Pires, A.S.; Schröder, R.; Rabelo, T.K.; Santos, J.P.A.; Lima, P.S.S.; Cavalcanti, S.C.H.; et al. Antinociceptive Activity and Redox Profile of the Monoterpenes (+)-Camphene, $p$-Cymene, and Geranyl Acetate in Experimental Models. Toxicology 2013, 2013, 11. [CrossRef] [PubMed]

32. Melo, M.S.; Santana, M.T.; Guimarães, A.G.; Siqueira, R.S.; de Sousa, D.P.; Santos, M.R.V.; Bonjardim, L.R.; Araujo, A.A.S.; Onofre, A.S.C.; Lima, J.T.; et al. Bioassay-guided evaluation of central nervous system effects of citronellal in rodents. Braz. J. Pharmacogn. 2011, 21, 697-703. [CrossRef]

33. Dresch, M.T.K.; Rossato, S.B.; Kappel, V.D.; Biegelmeyer, R.; Hoff, M.L.; Mayorga, P.; Zuanazzi, J.A.; Henriques, A.T.; Moreira, J.C. Optimization and validation of an alternative method to evaluate total reactive antioxidant potential. Anal. Biochem. 2009, 385, 107-114. [CrossRef] [PubMed]

34. Baser, K.H.C. Biological and pharmacological activities of carvacrol and carvacrol bearing essential oils. Curr. Pharm. Des. 2008, 14, 3106-3120. [CrossRef] [PubMed]

35. Koparal, A.T.; Zeytinoglu, M. Effects of carvacrol on a human nonsmall cell lung cancer (NSCLC) cell line, A549. Cytotecnology 2005, 43, 149-154. [CrossRef] [PubMed]

36. Jukic, M.; Politeo, O.; Maksimovic, M.; Milos, M. In vitro acetylcholinesterase inhibitory properties of thymol, carvacrol and their derivatives thymoquinone and thymohydroquinone. Phytother. Res. 2007, 21, 259-261. [CrossRef] [PubMed] 
37. Quintans-Júnior, L.J.; Guimarães, A.G.; Araújo, B.E.S.; Oliveira, G.F.; Santana, M.T.; Moreira, F.V.; Santos, M.R.V.; Cavalcanti, S.C.H.; de Lucca, J.W.; Botelho, M.A.; et al. Carvacrol, (-)-borneol and citral reduce convulsant activity in rodents. Afr. J. Biotechnol. 2010, 9, 6566-6572.

38. Melo, M.G.D.; Santos, J.P.A.; Serafini, M.R.; Caregnato, F.F.; Pasquali, M.A.; Rabelo, T.K.; Da Rocha, R.F.; Araújo, A.A.; Da Silva, F.A.; Moreira, J.C.; et al. Redox properties and cytoprotective actions of atranorin, a lichen secondary metabolite. Toxicol. In Vitro 2011, 25, 462-468. [CrossRef] [PubMed]

39. Guimarães, A.G.; Oliveira, G.F.; Melo, M.S.; Cavalcanti, S.C.; Antoniolli, A.R.; Bonjardim, L.R.; Silva, F.A.; Santos, J.P.; Rocha, R.F.; Moreira, J.C.; et al. Bioassayguided evaluation of antioxidant and antinociceptive activities of carvacrol. Basic Clin. Pharmacol. Toxicol. 2010, 107, 949-957. [CrossRef] [PubMed]

40. Melo, F.H.C.; Riosa, E.R.V.; Rocha, N.F.M.; Citóa, M.C.O.; Fernandes, M.L.; de Sousa, D.P.; Vasconcelos, S.M.M.; Sousa, F.C.F. Antinociceptive activity of carvacrol (5-isopropyl-2-methylphenol) in mice. J. Pharm. Pharmacol. 2012, 64, 1722-1729. [CrossRef] [PubMed]

41. Hotta, M.; Nakata, R.; Katsukawa, M.; Hori, K.; Takahashi, S.; Inoue, H. Carvacrol, a component of thyme oil, activates PPAR $\alpha$ and $\gamma$, and suppresses COX-2 expression. J. Lipid. Res. 2010, 51, 132-139. [CrossRef] [PubMed]

42. Guimarães, A.G.; Xavier, M.A.; de Santana, M.T.; Camargo, E.A.; Santos, C.A.; Brito, F.A.; Barreto, E.O.; Cavalcanti, S.C.H.; Antoniolli, A.R.; Oliveira, R.C.M.; et al. Carvacrol attenuates mechanical hypernociception and inflammatory response. Naunyn Schmiedebergs Arch. Pharmacol. 2012, 385, $253-263$. [CrossRef] [PubMed]

43. Guimarães, A.G.; Silva, F.V.; Xaviera, M.A.; Santos, M.R.V.; Rita, C.M.; Oliveira, R.C.M.; Oliveira, M.G.B.; Oliveira, A.P.; de Souza, C.C.; Quintans-Júnior, L.J. Orofacial Analgesic-Like Activity of Carvacrol in Rodents. Z. Naturforsch. 2012, 67, 481-485. [CrossRef]

44. Luo, Q.T.; Fujita, T.; Jiang, C.Y.; Kumamoto, E. Carvacrol presynaptically enhances spontaneous excitatory transmission and produces outward current in adult rat spinal substantia gelatinosa neurons. Brain Res. 2014, 1592, 44-54. [CrossRef] [PubMed]

45. Fürst, S. Transmitters involved in antinociception in the spinal cord. Brain Res. Bull. 1999, 48, $129-141$. [CrossRef]

46. Roberts, K.; Shenoy, R.; Anand, P. A novel human volunteer pain model using contact heat evoked potentials (CHEP) following topical skin application of transient receptor potential agonists capsaicin, menthol and cinnamaldehyde. J. Clin. Neurosc. 2011, 18, 926-932. [CrossRef] [PubMed]

47. Joca, H.C.; Cruz-Mendes, Y.; Oliveira-Abreu, K.; Maia-Joca, R.P.M.; Barbosa, R.; Lemos, T.L.; Beirão, P.S.L.; Leal-Cardoso, J.H. Carvacrol Decreases Neuronal Excitability by Inhibition of Voltage-Gated Sodium Channels. J. Nat. Prod. 2012, 75, 1511-1517. [CrossRef] [PubMed]

48. Katsuyama, S.; Kuwahata, H.; Yagi, T.; Kishikawa, Y.; Komatsu, T.; Sakurada, T.; Nakamura, H. Intraplantar injection of linalool reduces paclitaxel-induced acute pain in mice. Biol. Res. 2012, 33, 175-181. [CrossRef]

49. Peana, A.T.; D'Aquila, P.S.; Panin, F.; Serra, G.; Pippia, P.; Moretti, M.D.L. Anti-inflammatory activity of linalool and linalyl acetate constituents of essential oils. Phytomedicine 2002, 9, 721-726. [CrossRef] [PubMed]

50. Peana, A.T.; de Montis, M.G.; Sechi, S.; Sircana, G.; D'Aquila, P.S.; Pippia, P. Effects of (-)-linalool in the acute hyperalgesia induced by carrageenan, L-glutamate and prostaglandin E2. Eur. J. Pharmacol. 2004, 497, 279-284. [CrossRef] [PubMed]

51. Peana, A.T.; Marzocco, S.; Popolo, A.; Pinto, A. (-)-Linalool inhibits in vitro NO formation: Probable involvement in the antinociceptive activity of this monoterpene compound. Life Sci. 2006, 78, 719-723. [CrossRef] [PubMed]

52. Kamatou, G.P.P.; Viljoen, A.M. Linalool-A review of a biologically active compound of commercial importance. Nat. Prod. Commun. 2008, 3, 1183-1192.

53. Venâncio, A.M.; Marchioro, M.; Estavam, C.S.; Melo, M.S.; Santana, M.T.; Onofre, A.S.C.; Guimarães, A.G.; Oliveira, M.G.B.; Alves, P.B.; Pimentel, H.C.; et al. Ocimum basilicum leaf essential oil and (-)-linalool reduce orofacial nociception in rodents: A behavioral and electrophysiological approach. Braz. J. Pharmacog. 2011, 21, 1043-1051. [CrossRef]

54. Holanda-Pinto, S.A.; Pinto, L.M.S.; Guedes, M.A.; Cunha, G.M.A.; Chaves, M.H.; Santos, F.A.; Rao, V.S. Antinoceptive effect of triterpenoid $\alpha, \beta$-amyrin in rats on orofacial pain induced by formalin and capsaicin. Phytomedicine 2008, 15, 630-634. [CrossRef] [PubMed] 
55. Andersen, P.; Bliss, T.V.; Skrede, K.K. Unit analysis of hippocampal polulation spikes. Exp. Brain. Res. 1971, 13, 208-221. [CrossRef] [PubMed]

56. Kuwahata, H.; Komatsu, T.; Katsuyama, S.; Corasaniti, M.T.; Bagetta, G.; Sakurada, S.; Sakurada, T.; Kazuo Takahama, K. Peripherally injected linalool and bergamot essential oil attenuate mechanical allodynia via inhibiting spinal ERK phosphorylation. Pharmacol. Biochem. Behav. 2013, 103, 735-741. [CrossRef] [PubMed]

57. Galan, A.; Lopez-Garcia, J.A.; Cervero, F.; Laird, J.M. Activation of spinal extracelular signaling-regulated kinase-1 and -2 by intraplantar carrageenan in rodents. Neurosci. Lett. 2002, 322, 37-40. [CrossRef]

58. Ji, R.R.; Befort, K.; Brenner, G.J.; Woolf, C.J. ERK MAP kinase activation in superficial spinal cord neurons induces prodynorphin and NK-1 upregulation and contributes to persistent inflammatory pain hypersensitivity. J. Neurosci. 2002, 22, 478-485. [PubMed]

59. Ji, R.R.; Baba, H.; Brenner, G.J.; Woolf, C.J. Nociceptive-specific activation of ERK in spinal neurons contributes to pain hypersensitivity. Nat. Neurosci. 1999, 2, 1114-1119. [CrossRef] [PubMed]

60. Dai, Y.; Iwata, K.; Fukuoka, T.; Kondo, E.; Tokunaga, A.; Yamanaka, H.; Tachibana, T.; Liu, Y.; Noguchi, K. Phosphorylation of extracellular signal-regulated kinase in primary afferent neurons by noxious stimuli and its involvement in peripheral sensitization. J. Neurosci. 2002, 22, 7737-7745. [PubMed]

61. Komatsu, T.; Mizoguchi, H.; Sasaki, M.; Sakurada, C.; Tsuzuki, M.; Sakurada, S.; Sakurada, T. Inhibition of ERK phosphorylation by substance P N-terminal fragment decreases capsaicininduced nociceptive response. Neuropharmacology 2011, 61, 608-613. [CrossRef] [PubMed]

62. Katsuyama, S.; Otowa, A.; Kamio, S.; Sato, K.; Yagi, T.; Kishikawa, Y.; Komatsu, T.; Bagetta, G.; Sakurada, T.; Nakamura, H. Effect of plantar subcutaneous administration of bergamot essential oil and linalool on formalin-induced nociceptive behavior in mice. Biomed. Res. 2015, 36, 47-54. [CrossRef] [PubMed]

63. Al-Harrasi, A.; Ali, L.; Hussain, J.; Rehman, N.U.; Mehjabeen; Ahmed, M.; Al-Rawahi, A. Analgesic effects of crude extracts and fractions of Omani frankincense obtained from traditional medicinal plant Boswellia sacra on animal models. Asian Pac. J. Trop. Med. 2014, 7S1, S485-S490. [CrossRef]

64. Li, X.J.; Yang, Y.J.; Li, Y.S.; Zhang, W.K.; Tang, H.B. $\alpha$-Pinene, linalool, and1-octanol contribute to the topical anti-inflammatory and analgesic activities of frankincense by inhibiting COX-2. J. Ethnopharmacol. 2016, 179, 22-26. [CrossRef] [PubMed]

65. Tashiro, S.; Yamaguchi, R.; Ishikawa, S.; Sakurai, T.; Kajiya, K.; Kanmura, Y.; Kuwaki, T.; Kashiwadani, H. Odour-induced analgesia mediated by hypothalamic orexin neurons in mice. Sci. Rep. 2016, 6, 37129. [CrossRef] [PubMed]

66. Chiou, L.C.; Lee, H.J.; Ho, Y.C.; Chen, S.P.; Liao, Y.Y.; Ma, C.H.; Fan, P.C.; Fuh, J.L.; Wang, S.J. Orexins/hypocretins: Pain regulation and cellular actions. Curr. Pharm. 2010, 16, 3089-3100. [CrossRef]

67. Quintans-Júnior, L.J.; Barreto, R.S.; Menezes, P.P.; Almeida, J.R.; Viana, A.F.; Oliveira, R.C.; Oliveira, A.P.; Gelain, D.P.; de Lucca Júnior, W.; Araújo, A.A. $\beta$-Cyclodextrin-complexed (-)-linalool produces antinociceptive effect superior to that of (-)-linalool in experimental pain protocols. Basic Clin. Pharmacol. Toxicol. 2013, 113, 167-172. [CrossRef] [PubMed]

68. Nöldner, M.; Germer, S.; Koch, E. Pharmacokinetics of linalool and linalyl acetate, the two main constituents of silexan, an essential oil from Lavandula angustifolia flowers, in rats. Planta Med. 2011, 77, 44. [CrossRef]

69. Nascimento, S.S.; Camargo, E.A.; de Santana, J.M.; Araújo, A.A.S.; Menezes, P.P.; Lucca-Júnior, W.; Albuquerque-Júnior, R.L.C.; Bonjardim, L.R.; Quintans-Júnior, L.J. Linalool and linalool complexed in $\beta$-cyclodextrin produce anti-hyperalgesic activity and increase Fos protein expression in animal model for fibromyalgia. Naunyn Schmiedebergs Arch. Pharmacol. 2014, 387, 935-942. [CrossRef] [PubMed]

70. Szabadics, J.; Erdelyi, L. Pre- and post-synaptic effects of eugenol and related compounds on Helix pomatia L. neurons. Acta Biol. Hung. 2000, 51, 265-273. [PubMed]

71. Bó, W.D.; Luiz, A.P.; Martins, D.F.; Mazzardo-Martins, L.; Santos, A.R.S. Eugenol reduces acute pain in mice by modulating the glutamatergic and tumornecrosis factor $\alpha$ (TNF- $\alpha$ ) pathways. Fundament. Clin. Pharmacol. 2013, 27, 517-525.

72. Ohkubo, T.; Shibata, M. The selective capsaicin antagonista capsazepine abolishes the antinociceptive action of eugenol and guaiacol. J. Dent. Res. 1997, 76, 848-851. [CrossRef] [PubMed]

73. Park, S.H.; Sim, Y.B.; Lee, J.K.; Kim, S.M.; Kang, Y.J.; Jung, J.S.; Suh, H.W. The Analgesic Effects and Mechanisms of Orally Administered Eugenol. Arch. Pharm. Res. 2011, 34, 501-507. [CrossRef] [PubMed] 
74. Won, M.H.; Lee, J.C.; Kim, Y.H.; Song, D.K.; Suh, H.W.; Oh, Y.S.; Kim, J.H.; Shin, T.K.; Lee, Y.J.; Wie, M.B. Postischemic hypothermia induced by eugenol protects hippocampal neurons from global ischemia in gerbils. Neurosci. Lett. 1998, 254, 101-104. [CrossRef]

75. Dallmeier, K.; Carlini, E.A. Anesthetic, hypothermic, myorelaxant and anticonvulsant effects of synthetic eugenol derivatives and natural analogues. Pharmacology 1981, 22, 113-127. [CrossRef] [PubMed]

76. Feng, J.; Lipton, J.M. Eugenol: Antipyretic activity in rabbits. Neuropharmacology 1987, 26, 1775-1778. [CrossRef]

77. Lionnet, L.; Beaudry, F.; Vachon, P. Intrathecal eugenol administration alleviates neuropathic pain in male Sprague- Dawley rats. Phytother. Res. 2010, 24, 1645-1653. [CrossRef] [PubMed]

78. Park, C.K.; Kim, K.; Jung, S.J.; Kim, M.J.; Ahn, D.K.; Hong, S.D.; Kim, J.S.; Oh, S.B. Molecular mechanism for local anesthetic action of eugenol in the rat trigeminal system. Pain 2009, 144, 84-94. [CrossRef] [PubMed]

79. Paula-Freire, L.I.G.; Molska, G.R.; Andersen, M.L.; Carlini, E.L.A. Ocimum gratissimum Essential Oil and Its Isolated Compounds (Eugenol and Myrcene) Reduce Neuropathic Pain in Mice. Planta Med. 2016, 82, 211-216. [CrossRef] [PubMed]

80. Ferland, C.E.; Beaudry, F.; Vachon, P. Antinociceptive Effects of Eugenol Evaluated in a Monoiodoacetate-induced Osteoarthritis Rat Model. Phytother. Res. 2012, 26, 1278-1285. [CrossRef] [PubMed]

81. Tang, H.B.; Li, Y.S.; Miyano, K.; Nakata, Y. Phosphorylation of TRPV1 by neurokinin-1 receptor agonist exaggerates the capsaicin-mediated substance $\mathrm{P}$ release from cultured rat dorsal root ganglion neurons. Neuropharmacology 2008, 55, 1405-1411. [CrossRef] [PubMed]

82. Salo, P.T.; Theriault, E. Number, distribution and neuropeptide content of rat knee joint afferents. J. Anat. 1997, 190, 515-522. [CrossRef] [PubMed]

83. Klein, A.H.; Carstens, M.I.; Carstens, E. Eugenol and carvacrol induce temporally desensitizing patterns of oral irritation and enhance innocuous warmth and noxious heat sensation on the tongue. Pain 2013, 154, 2078-2087. [CrossRef] [PubMed]

84. Li, Y.L.; Tian, M.; Yu, J.; Shang, M.Y.; Cai, S.Q. Studies on morphology and aristolochic acid analogue constituents of Asarum campaniflorum and a comparison with two official species of Asari Radix et Rhizoma. J. Nat. Med. 2010, 64, 442-451. [CrossRef] [PubMed]

85. Lima, C.C.; Criddle, D.N.; Coelho-de-Souza, A.N.; Monte, F.J.; Jaffar, M.; Leal-Cardoso, J.H. Relaxant and antispasmodic actions of methyleugenol on guinea-pig isolated ileum. Planta Med. 2000, 66, 408-411. [CrossRef] [PubMed]

86. Wang, Z.J.; Tabakoff, B.; Levinson, S.R.; Heinbockel, T. Inhibition of Nav1.7 channels by methyl eugenol as a mechanism underlying its antinociceptive and anesthetic actions. Acta Pharmacol. Sin. 2015, 36, 791-799. [CrossRef] [PubMed]

87. Fônseca, D.V.; Salgado, P.R.R.; Aragão Neto, H.C.; Golzio, A.M.F.O.; Marcelo, R.D.; Caldas Filho, M.R.; Melo, C.G.; Leite, F.C.; Piuvezam, M.R.; Pordeus, L.C.M.; et al. Ortho-eugenol exhibits anti-nociceptive and anti-inflammatory activities. Int. Immunopharmacol. 2016, 38, 402-408. [CrossRef] [PubMed]

88. Liu, B.; Fan, L.; Balakrishna, S.; Sui, A.; Morris, J.B.; Jordt, S.E. TRPM8 is the Principal Mediator of Menthol-induced Analgesia of Acute and Inflammatory. Pain 2013, 154, 2169-2177. [CrossRef] [PubMed]

89. Bhatia, S.P.; McGinty, D.; Letizia, C.S.; Api, A.M. Fragrance material review on 1-menthol. Food Chem. Toxicol. 2008, 46, S218-S223. [CrossRef] [PubMed]

90. Green, B.G.; McAuliffe, B.L. Menthol desensitization of capsaicin irritation. Evidence of a short-term anti-nociceptive effect. Physiol. Behav. 2000, 68, 631-639. [CrossRef]

91. Borhani Haghighi, A.; Motazedian, S.; Rezaii, R.; Mohammadi, F.; Salarian, L.; Pourmokhtari, M.; Khodaei, S.; Vossoughi, M.; Miri, R. Cutaneous application of menthol 10\% solution as an abortive treatment of migraine without aura: A randomised, double-blind, placebo-controlled, crossed-over study. Int. J. Clin. Pract. 2010, 64, 451-456. [CrossRef] [PubMed]

92. Higashi, Y.; Kiuchi, T.; Furuta, K. Efficacy and safety profile of a topical methyl salicylate and menthol patch in adult patients with mild to moderate muscle strain: A randomized, double-blind, parallel-group, placebo-controlled, multicenter study. Clin. Ther. 2010, 32, 34-43. [CrossRef] [PubMed]

93. Klein, A.H.; Sawyer, C.M.; Carstens, M.I.; Tsagareli, M.G.; Tsiklauri, N.; Carstens, E. Topical application of L-menthol induces heat analgesia, mechanical allodynia, and a biphasic effect on cold sensitivity in rats. Behav. Brain. Res. 2010, 212, 179-186. [CrossRef] [PubMed] 
94. Pan, R.; Tian, Y.; Gao, R.; Li, H.; Zhao, X.; Barrett, J.E.; Hu, H. Central Mechanisms of Menthol-Induced Analgesia. J. Pharmacol. Exp. Ther. 2012, 343, 661-672. [CrossRef] [PubMed]

95. Hatem, S.; Attal, N.; Willer, J.C.; Bouhassira, D. Psychophysical study of the effects of topical application of menthol in healthy volunteers. Pain 2006, 122, 190-196. [CrossRef] [PubMed]

96. Wasner, G.; Naleschinski, D.; Binder, A.; Schattschneider, J.; McLachlan, E.M.; Baron, R. The effect of menthol on cold allodynia in patients with neuropathic pain. Pain Med. 2008, 9, 354-358. [CrossRef] [PubMed]

97. Gentry, C.; Stoakley, N.; Andersson, D.A.; Bevan, S. The roles of iPLA2, TRPM8 and TRPA1 in chemically induced cold hypersensitivity. Mol. Pain 2010, 6, 4. [CrossRef] [PubMed]

98. Knowlton, W.M.; Bifolck-Fisher, A.; Bautista, D.M.; McKemy, D.D. TRPM8, but not TRPA1, is required for neural and behavioral responses to acute noxious cold temperatures and cold-mimetics in vivo. Pain 2010, 150, 340-350. [CrossRef] [PubMed]

99. Macpherson, L.J.; Hwang, S.W.; Miyamoto, T.; Dubin, A.E.; Patapoutian, A.; Story, G.M. More than cool: Promiscuous relationships of menthol and other sensory compounds. Mol. Cell. Neurosci. 2006, 32, 335-343. [CrossRef] [PubMed]

100. Karashima, Y.; Talavera, K.; Everaerts, W.; Janssens, A.; Kwan, K.Y.; Vennekens, R.; Nilius, B.; Voets, T. TRPA1 acts as a cold sensor in vitro and in vivo. Proc. Natl. Acad. Sci. USA 2009, 106, 1273-1278. [CrossRef] [PubMed]

101. Takaishi, M.; Uchida, K.; Suzuki, Y.; Matsui, H.; Shimada, T.; Fujita, F.; Tominaga, M. Reciprocal effects of capsaicin and menthol on thermosensation through regulated activities of TRPV1 and TRPM8. J. Physiol. Sci. 2016, 66, 143-155. [CrossRef] [PubMed]

102. Abe, J.; Hosokawa, H.; Okazawa, M.; Kandachi, M.; Sawada, Y.; Yamanaka, K.; Matsumura, K.; Kobayashi, S. TRPM8 protein localization in trigeminal ganglion and taste papillae. Brain. Res. Mol. Brain. Res. 2015, 13, 91-98. [CrossRef] [PubMed]

103. Kobayashi, K.; Fukuoka, T.; Obata, K.; Yamanaka, H.; Dai, Y.; Tokunaga, A.; Noguchi, K. Distinct expression of TRPM8, TRPA1, and TRPV1 mRNAs in rat primary afferent neurons with adelta/c-fibers and colocalization with trk receptors. J. Comp. Neurol. 2005, 493, 596-606. [CrossRef] [PubMed]

104. Vichnewski, W.; Takahashi, A.M.; Nasi, A.M.T.; Gonçalves, D.C.R.G.; Dias, D.A.; Lopes, J.N.C.; Goedken, V.L.; Gutierrez, A.B.; Herz, W. Sesquiterpene lactones and other constituents from Eremanthus seidelli, E. goyazensis and Vanillosmopsis erythropappa. Phytochemistry 1989, 29, 1441-1451. [CrossRef]

105. De Lira, P.N.; Andrade, E.H.; Sousa, P.J.; Silva, N.N. Essential oil composition of three Peperomia species from the Amazon, Brazil. Nat. Prod. Commun. 2009, 4, 427-430. [PubMed]

106. Reynolds, J.E.F. Martindale, the Extra Pharmacopoeia; The Pharmaceutical: London, UK, 1996.

107. Rocha, N.F.M.; Rios, E.R.V.; Carvalho, A.M.R.; Cerqueira, G.S.; Lopes, A.A.; Leal, L.K.A.M.; Dias, M.L.; de Sousa, D.P.; Sousa, F.C.F. Anti-nociceptive and anti-inflammatory activities of (-)- $\alpha$-bisabolol in rodents. Naunyn Schmiedebergs Arch. Pharmacol. 2011, 384, 525-533. [CrossRef] [PubMed]

108. Villegas, L.F.; Marçalo, A.; Martin, J.; Fernández, I.D.; Maldonado, H.; Vaisberg, A.J.; Hammond, G.B. (+) epi- $\alpha$-bisabolol [correction of bisbolol] is the wound-healing principle of Peperomia galioides: Investigation of the in vivo wound-healing activity of related terpenoids. J. Nat. Prod. 2001, 64, 1357-1359. [CrossRef] [PubMed]

109. Bezerra, S.B.; Leal, L.K.; Nogueira, N.A.; Campos, A.R. Bisabolol-induced gastroprotection against acute gastric lesions: Role of prostaglandins, nitric oxide, and KATP+ channels. J. Med. Food. 2009, 12, 1403-1406. [CrossRef] [PubMed]

110. Da Silva, A.P.; Martini, M.V.; de Oliveira, C.M.; Cunha, S.; de Carvalho, J.E.; Ruiz, A.L.; da Silva, C.C. Antitumor activity of $(-)$ - $\alpha$-bisabolol-based thiosemicarbazones against human tumor cell lines. Eur. J. Med. Chem. 2010, 45, 2987-2993. [CrossRef] [PubMed]

111. Braga, P.C.; Dal Sasso, M.; Fonti, E.; Culici, M. Antioxidant activity of bisabolol: Inhibitory effects on chemiluminescence of human neutrophil bursts and cell-free systems. Pharmacology 2009, 83, 110-115. [CrossRef] [PubMed]

112. Morales-Yuste, M.; Morillas-Márquez, F.; Martín-Sánchez, J.; Valero-López, A.; Navarro-Moll, M.C. Activity of $(-) \alpha$-bisabolol against Leishmania infantum promastigotes. Phytomedicine 2010, 17, 279-281. [CrossRef] [PubMed] 
113. Alves, A.M.; Gonçalves, J.C.; Cruz, J.S.; Araújo, D.A. Evaluation of the sesquiterpene (-)- $\alpha$-bisabolol as a novel peripheral nervous blocker. Neurosci. Lett. 2010, 472, 11-15. [CrossRef] [PubMed]

114. Leite, G.O.; Leite, L.H.I.; Sampaio, R.S.; Araruna, M.K.A.; Menezea, I.R.A.; Costa, J.G.M.; Campos, A.R. (-)- $\alpha$-Bisabolol attenuates visceral nociception and inflammation in mice. Fitoterapia 2011, 82, $208-211$. [CrossRef] [PubMed]

115. Leite, G.O.; Fernandes, C.N.; Menezes, I.R.A.; Costa, J.G.M.; Campos, A.R. Attenuation of visceral nociception by $\alpha$-bisabolol in mice: Investigation of mechanisms. Org. Med. Chem. Lett. 2012, 2, 18. [CrossRef] [PubMed]

116. Nurulain, S.; Prytkova, T.; Sultan, A.M.; Ievglevskyi, O.; Lorke, D.; Yang, K.H.S.; Petroianu, G.; Howarth, F.C.; Kabbani, N.; Oz, M. Inhibitory actions of bisabolol on $\alpha 7$-nicotinicacetylcholine receptors. Neuroscience 2015, 306, 91-99. [CrossRef] [PubMed]

117. Albuquerque, E.X.; Pereira, E.F.; Alkondon, M.; Rogers, S.W. Mammalian nicotinic acetylcholine receptors: From structure to function. Physiol. Rev. 2009, 89, 73-120. [CrossRef] [PubMed]

118. Minae, B.; Sardari, M.; Sharifi, H.; Abadi, M.S.R.; Sadeghpour, O. Stachys lavandulifolia Vahl. and its relation with marmazad activities in traditional manuscripts. Iran. Red Crescent Med. J. 2015, 17, 19932. [CrossRef] [PubMed]

119. Barreto, R.S.S.; Quintans, J.S.S.; Amarante, R.K.L.; Nascimento, T.S.; Amarante, R.S.; Barreto, A.S.; Pereira, E.W.M.; Duarte, M.C.; Coutinho, H.D.M.; Menezes, I.R.A.; et al. Evidence for the involvement of TNF- $\alpha$ and IL-1 $\beta$ in the antinociceptive and anti-inflammatory activity of Stachys lavandulifolia Vahl. (Lamiaceae) essential oil and (-)- $\alpha$-bisabolol, its main compound, in mice. J. Ethnopharmacol. 2016, 191, 9-18. [CrossRef] [PubMed]

120. Rao, P.V.; Gan, S.H. Cinnamon: A multifaceted medicinal plant. Evid. Based Complem. Alternat. Med. 2014, 2014, 12. [CrossRef] [PubMed]

121. Ali, S.M.; Khan, A.A.; Musaddiq, I.A.M.; Ahmed, K.S.; Polasa, H.; Rao, L.V.; Habibullah, C.M.; Sechi, L.A.; Ahmed, N. Antimicrobial activities of eugenol and cinnamaldehyde against the human gastric pathogen Helicobacter Pylori. Ann. Clin. Microbil. Antimicrob. 2005, 4, 1-7.

122. Sharma, U.K.; Sharma, A.K.; Pandey, A.K. Medicinal attributes of major phenylpropanoids present in cinnamon. BMC Complement Altern. Med. 2016, 31, 156. [CrossRef] [PubMed]

123. Youn, H.S.; Lee, J.K.; Choi, Y.J.; Saitoh, S.I.; Miyake, K.; Hwanq, D.H.; Lee, J.Y. Cinnamaldehyde suppresses toll-like receptor 4 activation mediated through the inhibition of receptor oligomerization. Biochem. Pharmacol. 2008, 75, 494-502. [CrossRef] [PubMed]

124. Mohammad, H.D.R.; Mohammad, D.Q.; Farzane, S.M.D.; Mohammadreza, N.Y.; Seyyed, M.B. Comparative effect of Cinnamon essential oil, diclofenac and morphine on acute and chronic pain in mice. Int. J. Med. Lab. 2016, 3, 92-103.

125. Churihar, R.; Solanki, P.; Vyas, S.; Hemant Tanwani, H.; Shubham Atal, S. Analgesic activity of cinnamaldehyde per se and it's interaction with diclofenac sodium and pentazocine in swiss albino mice. Int. J. Phamacog. 2016, 3, 97-102.

126. Trongtokit, Y.; Rongsriyam, Y.; Komalamisra, N.; Apiwathnasorn, C. Comparative Repellency of 38 Essential Oils against Mosquito Bites. Phytother. Res. 2005, 19, 303-309. [CrossRef] [PubMed]

127. Aakanksha, W.; Shivesh, J.; Vinod, K.N.; Dev, M.P. Chemical analysis and therapeutic uses of citronella oil from Cymbopogon winterianus: A short review. Int. J. Adv. Res. 2013, 1, 504-521.

128. Lu, Y.; Khoo, T.J.; Wiart, C. Antioxidant activity determination of citronellal and crude extracts of Cymbopogon citratus by 3 different methods. Pharmacol. Pharm. 2014, 5, 395-400. [CrossRef]

129. Leite, B.L.S.; Bonfim, R.R.; Antoniolli, A.R.; Tomazzi, S.M.; Araújo, A.A.S.; Blank, A.F.; Estevam, C.S.; Cambui, E.V.F.; Bonjardim, L.R.; Albuquerque Júnior, R.L.C.; et al. Assessment of antinociceptive, anti-inflammatory and antioxidant properties of Cymbopogon winterianus leaf essential oil. Pharm. Biol. 2010, 48, 1164-1169. [CrossRef] [PubMed]

130. Quintans-Júnior, L.J.; Rocha, R.F.; Caregnato, F.F.; Moreira, J.C.F.; Silva, F.A.; Araújo, A.A.S.; Santos, J.P.A.; Melo, M.S.; Sousa, D.P.; Bonjardim, L.R.; et al. Antinociceptive action and redox properties of citronellal, an essential oil present in Lemongrass. J. Med. Food 2011, 14, 630-639. [CrossRef] [PubMed]

131. Santana, M.T.; Oliveira, M.B.; Santana, M.F.; de Sousa, D.P.; Santana, D.G.; Camargo, E.A.; Oliveira, A.P.; Almeida, J.R.G.S.; Quintans-Júnior, L.J. Citronellal, a monoterpene present in Java citronella oil, attenuates mechanical nociception response in mice. Pharm. Biol. 2013, 51, 1144-1149. [CrossRef] [PubMed] 
132. Tavares, E.S.; Julião, L.S.; Lopes, D.; Bizzo, H.R.; Lage, C.L.S.; Leitão, S.G. Análise do óleo essencial de folhas de quimiotipos de Lippia alba (Mill.) N.E. Br. (Verbenaceae) cultivados em condições semelhantes. Braz. J. Pharmacog. 2005, 15, 1-5. [CrossRef]

133. Chanthai, S.; Prachakoll, S.; Ruangviriyachai, C.; Luthria, D.L. Influence of extraction methodologies on the analysis of five major volatile aromatic compounds of citronella grass (Cymbopogon nardus) and lemongrass (Cymbopogon citratus) grown in Thailand. J. AOAC Int. 2012, 95, 763-772. [CrossRef] [PubMed]

134. Rao, B.R.R.; Bhattacharya, A.K.; Mallavarapu, G.R.; Ramesh, S. Yellowing and crinkling disease and its impact in the yield and composition of the essential oil of citronella (Cymbopogon winterianus Jowitt.). Flavour Frag. J. 2004, 19, 344-350.

135. Katsukawa, M.; Nakata, R.; Koeji, S.; Hori, K.; Takahashi, S.; Inoue, H. Citronellol and geraniol, components of rose oil, activate peroxisome proliferator-activated receptor $\alpha$ and $\gamma$ and suppress cyclooxygenase-2 expression. Biosci. Biotechnol. Biochem. 2011, 75, 1010-1012. [CrossRef] [PubMed]

136. Sharopov, F.S.; Zhang, H.; Setzer, W.N. Composition of geranium (Pelargonium graveolens) essential oil from Tajikistan. Am. J. Essent. Oil. Nat. Prod. 2014, 2, 13-16.

137. Viana, G.S.; Vale, T.G.; Pinho, R.S.; Matos, F.J. Antinociceptive effect of the essential oil from Cymbopogon citratus in mice. J. Ethnopharmacol. 2000, 70, 323-327. [CrossRef]

138. Boukhatem, M.N.; Kameli, A.; Ferhat, M.A.; Saidi, F.; Mekarnia, M. Rose geranium essential oil as a source of new and safe anti-inflammatory drugs. Libyan J. Med. 2013, 7, 22520. [CrossRef] [PubMed]

139. Brito, R.G.; Guimarães, A.G.; Quintans, J.S.S.; Santos, M.R.V.; de Sousa, D.P.; Passos, D.B., Jr.; Lucca Junior, W.; Brito, F.A.; Barreto, E.O.; Oliveira, A.P.; et al. Citronellol, a monoterpene alcohol, reduces nociceptive and inflammatory activities in rodents. J. Nat. Med. 2012, 66, 637-644. [CrossRef] [PubMed]

140. Brito, R.G.; Santos, P.L.; Prado, D.S.; Santana, M.T.; Araújo, A.A.; Bonjardim, L.R.; Santos, M.R.; de Lucca Júnior, W.; Oliveira, A.P.; Quintans-Júnior, L.J. Citronellol reduces orofacial nociceptive behaviour in mice-Evidence of involvement of retrosplenial cortex and periaqueductal grey areas. Basic Clin. Pharmacol. Toxicol. 2013, 112, 215-221. [CrossRef] [PubMed]

141. Brito, R.G.; Santos, P.L.; Quintans, J.S.S.; de Lucca Júnior, W.; Araújo, A.A.S.; Saravanan, S.; Menezes, I.R.A.; Coutinho, H.D.M.; Quintans-Júnior, L.J. Citronellol, a natural acyclic monoterpene, attenuates mechanical hyperalgesia response in mice: Evidence of the spinal cord lamina I inhibition. Chem. Biol. Interact. 2015, 239, 111-117. [CrossRef] [PubMed]

142. Rios, E.R.V.; Rocha, N.F.M.; Carvalho, A.M.R.; Vasconcelos, L.F.; Dias, M.L.; Sousa, D.P.; Sousa, F.C.F.; Fonteles, M.M.F. TRP and ASIC channels mediate the antinociceptive effect of citronellyl acetate. Chem. Biol. Interact. 2013, 203, 573-579. [CrossRef] [PubMed]

143. Loumouamou, A.N.; Silou, T.; Mapola, G.; Chalchat, J.C.; Figuérédo, G. Yield and composition of essential oils from Eucalyptus citriodora x Eucalyptus torelliana, a hybrid species growing in Congo-Brazzaville. J. Essent. Oil Res. 2009, 21, 295-299. [CrossRef]

144. Paik, S.Y.; Koh, K.H.; Beak, S.M.; Paek, S.H.; Kim, J.A. The essential oils from Zanthoxylum schinifolium pericarp induce apoptosis of HepG2 human hepatoma cells through increased production of reactive oxygen species. Biol. Pharm. Bull. 2005, 28, 802-807. [CrossRef] [PubMed]

145. Silva, J.; Abebe, W.; Sousa, S.M.; Duarte, V.G.; Machado, M.I.; Matos, F.J. Analgesic and anti-inflammatory effects of essential oils of Eucalyptus. J. Ethnopharmacol. 2003, 89, 277-283. [CrossRef] [PubMed]

146. Siqueira, H.D.A.S.; Neto, B.S.; Sousa, D.P.; Gomes, B.S.; Silva, F.V.; Cunha, F.V.M.; Wanderley, C.W.S.; Pinheiro, G.; Cândido, A.G.F.; Wong, D.V.T.; et al. $\alpha$-Phellandrene, a cyclic monoterpene, attenuates inflammatory response through neutrophil migration inhibition and mast cell degranulation. Life Sci. 2016, 160, 27-33. [CrossRef] [PubMed]

147. Hajhashemi, V.; Abbasi, N. Hypolipidemic activity of Anethum graveolens in rats. Phytother. Res. 2008, 22, 372-375. [CrossRef] [PubMed]

148. Essien, E.E.; Ogunwande, I.A.; Setzer, W.N.; Ekundayo, O. Chemical composition, antimicrobial, and cytotoxicity studies on S. erianthum and S. macranthum essential oils. Pharm. Biol. 2012, 50, 474-480. [CrossRef] [PubMed]

149. Nascimento, A.F.; Camara, C.A.; Moraes, M.M.; Ramos, C.S. Essential oil composition and acaricidal activity of Schinus terebinthifolius from Atlantic Forest of Pernambuco, Brazil against Tetranychusurticae. Nat. Prod. Commun. 2012, 7, 129-132. 
150. Singh, G.; Singh, O.P.; Maurya, S. Chemical and biocidal investigation on essential oil of some Indian Curcuma species. Prog. Cryst. Growth Charact. Mater. 2002, 45, 75-81. [CrossRef]

151. Asbaghian, S.; Shafaghat, A.; Zarea, K.; Kasimov, F.; Salimi, F. Comparison of volatile constituents, and antioxidant and antibacterial activities of the essential oils of Thymus caucasicus, T. kotschyanus and T. vulgaris. Nat. Prod. Commun. 2011, 6, 137-140.

152. Arjouni, M.Y.; Bahri, F.; Romane, A.; El Fels, M.A. Chemical composition and antimicrobial activity of essential oil of Cupressus atlantica. Nat. Prod. Commun. 2011, 6, 1519-1522. [PubMed]

153. Vitalini, S. Traditional uses of medicinal plants in Valvestino (Italy). J. Ethnopharmacol. 2009, 121, $106-116$. [CrossRef] [PubMed]

154. Erazo, S.; Delporte, C.; Negrete, R.; Garcıa, R.; Zaldıvar, M.; Iturra, G.; Caballero, E.; Lopez, J.L.; Backhouse, N. Constituents and biological activities of Schinus polygamus. J. Ethnopharmacol. 2006, 107, 395-400. [CrossRef] [PubMed]

155. Vendruscolo, A.; Takaki, I.; Bersani-Amado, L.E.; Dantas, J.A.; Bersani-Amado, C.A.; Cuman, R.K.N. Antiinflammatory and antinociceptive activities of Zingiber officinale roscoe essential oil in experimental animal models. Indian J. Pharmacol. 2006, 38, 58-59.

156. Lima, D.F.; Brandão, M.S.; Moura, J.B.; Leitão, J.M.; Carvalho, F.A.; Miúra, L.M.; Leite, J.R.; Sousa, D.P.; Almeida, F.R. Antinociceptive activity of the monoterpene $\alpha$-phellandrene in rodents: Possible mechanisms of action. J. Pharm. Pharmacol. 2012, 64, 283-292. [CrossRef] [PubMed]

157. Siani, A.C.; Nakamura, M.J.; Das Neves, G.P.; Monteiro, S.S.; Ramos, M.F.S. Leaf essential oil from three exotic Myrtaceae species growing in the Botanical Garden of Rio de Janeiro, Brazil. Am. J. Plant Sci. 2016, 7, 834-840. [CrossRef]

158. Wolffenbuttel, A.N.; Zamboni, A.; Santos, M.K.; Borille, B.T.; Augustin, O.A.; Mariotti, K.C.; Leal, M.B.; Limberger, P.R. Chemical components of Citrus essential oils from Brazil. Nat. Prod. J. 2015, 5, 14-27. [CrossRef]

159. Bibak, H.; Ali, A. Essential oil composition of stems, leaves and flowers of Nepeta dschuparensis Bornm from Kerman, Iran. J. Essent. Oil Bear. Plants 2017, 20, 597-600. [CrossRef]

160. Quintans-Júnior, L.J.; Oliveira, M.G.; Santana, M.F.; Santana, M.T.; Guimarães, A.G.; Siqueira, J.S.; de Sousa, D.P.; Almeida, R.N. $\alpha$-Terpineol reduces nociceptive behavior in mice. Pharm Biol. 2011, 49, 583-586. [CrossRef] [PubMed]

161. Kumar, R.; Sharma, P.K.; Mishra, P.S. A review on the vanillin derivatives showing various biological activities. Int. J. Pharm.Tech. Res. 2012, 4, 266-279.

162. Shoeb, A.; Chowta, M.; Pallempati, G.; Rai, A.; Singh, A. Evaluation of antidepressant activity of vanillin in mice. Indian J. Pharmacol. 2013, 45, 141-144. [PubMed]

163. Kinga, A.A.; Shaughnessy, D.T.; Murea, K.; Leszczynska, J.; Ward, W.O.; Umbach, D.M. Anti mutagenicity of cinnamaldehyde and vanillin in human cells: Global gene expression and possible role of DNA damage and repair. Mutat. Res. 2007, 616, 609.

164. Makni, M.; Chtourou, Y.; Fetoui, H.; Garoui el, M.; Boudawara, T.; Zeghal, N. Evaluation of the antioxidant, anti-inflammatory and hepato protective properties of vanillin in carbon tetrachloride-treated rats. Eur. J. Pharmacol. 2011, 668, 133-139. [CrossRef] [PubMed]

165. Bezerra, D.P.; Soares, A.K.; de Sousa, D.P. Overview of the Role of Vanillin on Redox Status and Cancer Development. Oxid. Med. Cell. Longev. 2016, 2016, 9734816. [CrossRef] [PubMed]

166. Park, S.; Sim, Y.; Choi, S.; Seo, Y.; Kwon, M.; Lee, J.; Suh, W.H. Antinociceptive profiles and mechanisms of orally administered vanillin in the mice. Arch. Pharm. Res. 2009, 32, 1643-1649. [CrossRef] [PubMed]

167. Rathnakar, U.P.; Srikanth, D.; Menezes, V.H.; Shenoy, K.; Ashok, A.; Sahana, D.; Nishchal, B.S.; Shivaprakash, G.; Udupa, A.L. Evaluation of antinociceptive activity of Vanillin mediated through opioid receptors. Drug Invent. Today 2012, 4, 674-676.

168. Srikanth, D.; Vishma, H.M.; Nischal, S.; Rathnakar, U.P.; Shiv, P.G.; Sahana, D.A.; Ashok, S.K.; Udupa, A.L. Evaluation of anti-inflammatory property of vanillin in carrageenan induced paw edema model in rats. Int. J. Bioassays 2013, 2, 269-271.

169. Sharan, A. Anti-inflammatory and antinociceptive activity of vanillin. Chem. Sci. J. 2016, 7, 3. 
170. Granger, R.E.; Campbell, E.L.; Johnston, G.A. (+)- And (-)-borneol: Efficacious positive modulators of GABA action at human recombinant $\alpha_{1} \beta_{2} \gamma_{2 L}$ GABAA receptors. Biochem. Pharmacol. 2005, 69, 1101-1111. [CrossRef] [PubMed]

171. Silva-Filho, J.C.; Oliveira, N.N.; Arcanjo, D.D.; Quintans-Júnior, L.J.; Cavalcanti, S.C.; Santos, M.R.; Oliveira, R.C.; Oliveira, A.P. Investigation of mechanisms involved in (-)-borneol-induced vasorelaxant response on rat thoracic aorta. Basic Clin. Pharmacol. Toxicol. 2012, 110, 171-177. [CrossRef] [PubMed]

172. Hattori, A. Camphor in the Edo era-camphor and borneol for medicines. Yakushigaku Zasshi 2000, 35, 49-54. [PubMed]

173. Zhong, W.; Cui, Y.; Yu, Q.; Xie, X.; Liu, Y.; Wei, M.; Ci, X.; Peng, L. Modulation of LPS-stimulated pulmonary inflammation by borneol in murine acute lung injury model. Inflammation 2014, 37, 1148-1157. [CrossRef] [PubMed]

174. Liu, R.; Zhang, L.; Lan, X.; Zhang, T.T.; Sun, J.H.; Du, G.H. Protection by borneol on cortical neurons against oxygen-glucose deprivation/reperfusion: Involvement of anti-oxidation and anti-inflammation through nuclear transcription factor $\gamma$ B signaling pathway. Neurosci. 2011, 176, 408-419. [CrossRef] [PubMed]

175. Almeida, J.R.G.S.; Souza, G.R.; Silva, J.; Saraiva, S.R.G.L.; Oliveira Júnior, R.G.; Quintans, J.S.S.; Barreto, R.S.S.; Bonjardim, L.R.; Cavalcanti, S.C.H.; Quintans Júnior, L.J. Borneol, a bicyclic monoterpene alcohol, reduces nociceptive behavior and inflammatory response in mice. Sci. World J. 2013, 2013, 808460. [CrossRef] [PubMed]

176. Jiang, J.; Shen, Y.Y.; Li, J.; Lin, Y.H.; Luo, C.X.; Zhu, D.Y. (+)-Borneol alleviates mechanical hyperalgesia in models of chronic inflammatory and neuropathic pain in mice. Eur. J. Pharmacol. 2015, 757, 53-58. [CrossRef] [PubMed]

177. Verma, R.S.; Padalia, R.C.; Yadav, A.; Chauhan, A. Essential Oil Composition of Aralia cachemirica from Uttarakhand, India. Rec. Nat. Prod. 2010, 4, 163-166.

178. Mockute, D.; Judzentiene, A. The myrtenol chemotype of essential oil of Tanacetum vulgare L. var. vulgare (tansy) growing wild in the Vilnius region. Chemija 2003, 14, 103-107.

179. Bell, S.G.; Chen, X.; Sowden, R.J.; Xu, F.; Williams, J.N.; Wong, L.L.; Rao, Z. Molecular recognition in (+)- $\alpha$-pinene oxidation by cytochrome P450cam. J. Am. Chem. Soc. 2003, 125, 705-714. [CrossRef] [PubMed]

180. De Sousa, D.P.; Nóbrega, F.F.F.; Claudino, F.S.; Almeida, R.N.; Leite, J.R.; Mattei, R. Pharmacological effects of the monoterpene $\alpha, \beta$-epoxy-carvone in mice. Rev. Bras. Farmacogn. 2007, 17, 170-175. [CrossRef]

181. Santos, M.R.V.; Moreira, F.V.; Fraga, B.P.; de Sousa, D.P.; Bonjardim, L.R.; Quintans-Junior, L.J. Cardiovascular effects of monoterpenes: A review. Rev. Bras. Pharmacogn. 2011, 21, 764-771. [CrossRef]

182. Ngan, L.T.M.; Moon, J.K.; Kim, J.H.; Shibamoto, T.; Ahn, Y.J. Growth-inhibiting effects of Paeonia lactiflora root steam distillate constituents and structurally related compounds on human intestinal bacteria. World J. Microbiol. Biotechnol. 2012, 28, 1575-1583. [CrossRef] [PubMed]

183. Silva, R.O.; Salvadori, M.S.; Sousa, F.B.M.; Santos, M.S.; Carvalho, N.S.; Sousa, D.P.; Gomes, B.S.; Oliveira, F.A.; Barbosa, A.L.R.; Freitas, R.M.; et al. Evaluation of the anti-inflammatory and antinociceptive effects of myrtenol, a plant derived monoterpene alcohol, in mice. Flavour Fragr. J. 2014, 29, 184-192. [CrossRef]

184. Solis-Quispe, L.; Tomaylla-Cruz, C.; Callo-Choquelvica, Y.; Solís-Quispe, A.; Rodeiro, I.; Hernández, I.; Fernández, M.D.; Pino, J.A. Chemical composition, antioxidant and antiproliferative activities of essential oil from Schinus areira L. and Minthostachys spicata (Benth.) Epl. grown in Cuzco, Peru. J. Essent. Oil Res. 2015, 28, 234-240. [CrossRef]

185. Mikaili, P.; Mojaverrostami, S.; Moloudizargari, M.; Aghajanshakeri, S. Pharmacological and therapeutic effects of Mentha longifolia L. and its main constituent, menthol. Anc. Sci. Life 2013, 33, 131-138. [PubMed]

186. Lorenzo, D.; Paz, D.; Dellacassa, E.; Davies, P.; Vila, R.; Salvador, C. Essential oils of Mentha pulegium and Mentha rotundifolia from Uruguay. Braz. Arch. Biol. Technol. 2002, 45, 519-524. [CrossRef]

187. Devi, R.C.; Sim, S.M.; Ismail, R. Spasmolytic effect of citral and extracts of Cymbopogon citratus on isolated rabbit ileum. J. Smooth Muscle Res. 2011, 47, 143-156. [CrossRef] [PubMed]

188. Olorunnisola, S.K.; Asiyanbi, H.T.; Hammed, A.M.; Simsek, S. Biological properties of lemongrass: An overview. Int. Food Res. J. 2014, 21, 455-462.

189. Nishijima, C.M.; Ganev, E.G.; Mazzardo-Martins, L.; Martins, D.F.; Rocha, L.R.M.; Santos, A.R.S.; Hiruma-Lima, C.A. Citral: A monoterpene with prophylactic and therapeutic anti-nociceptive effects in experimental models of acute and chronic pain. Eur. J. Pharmacol. 2014, 736, 16-25. [CrossRef] [PubMed] 
190. Peixoto-Neves, D.; Silva-Alves, K.S.; Gomes, M.D.; Lima, F.C.; Lahlou, S.; Magalhães, P.J.; Ceccatto, V.M.; Coelho-de-Souza, A.N.; Leal-Cardoso, J.H. Vasorelaxant effects of the monoterpenic phenol isomers, carvacrol and thymol, on rat isolated aorta. Fundam. Clin. Pharmacol. 2010, 24, 341-350. [CrossRef] [PubMed]

191. Angeles-López, G.; Pérez-Vásquez, A.; Hernández-Luis, F.; Déciga-Campos, M.; Bye, R.; Linares, E.; Mata, R. Antinociceptive effect of extracts and compounds from Hofmeisteria schaffneri. J. Ethnopharmacol. 2010, 131, 425-432. [CrossRef] [PubMed]

192. Fachini-Queiroz, F.C.; Kummer, R.; Estevão-Silva, C.F.; Carvalho, M.D.B.; Cunha, J.M.; Grespan, R.; Bersani-Amado, C.A.; Cuman, R.K.N. Effects of thymol and carvacrol, constituents of Thymus vulgaris L. essential oil, on the inflammatory response, Evid. Based Complement. Altern. Med. 2012, 2012, 1-10. [CrossRef] [PubMed]

193. Kaji, I.; Karaki, S.; Kuwahara, A. Effects of luminal thymol on epithelial transport in human and rat colon. J. Physiol. Gastrointest. Liver Physiol. 2011, 300, G1132-G1143. [CrossRef] [PubMed]

194. Xu, Z.H.; Wang, C.; Fujita, T.; Jiang, C.Y.; Kumamoto, E. Action of thymol on spontaneous excitatory transmission in adult rat spinal substantia gelatinosa neurons. Neurosci. Lett. 2015, 606, 94-99. [CrossRef] [PubMed]

195. Palazzolo, E.; Laudicina, V.A.; Germanà, M.A. Current and potential use of Citrus essential oils. Curr. Org. Chem. 2013, 17, 3042-3049. [CrossRef]

196. Jezler, C.N.; Oliveira, A.R.M.F.; Batista, R.S.; Oliveira, R.A.; Silva, D.C.; Costa, L.C.B. Lippia alba morphotypes cidreira and melissa exhibit signifcant differences in leaf characteristics and essential oil profile. Braz. J. Pharmacog. 2013, 23, 217-223. [CrossRef]

197. Obolskiy, D.; Pischel, I.; Feistel, B.; Glotov, N.; Heinrich, M. Artemisia dracunculus L. (Tarragon): A critical review of its traditional use, chemical composition, pharmacology, and safety. J. Agr. Food Chem. 2011, 59, 11367-11384. [CrossRef] [PubMed]

198. Yoon, W.J.; Lee, N.H.; Hyun, C.G. Limonene suppresses lipopolysaccharide-induced production of nitric oxide, prostaglandin E2, and pro-inflammatory cytokines in RAW 264.7 macrophages. J. Oleo Sci. 2010, 59, 415-421. [CrossRef] [PubMed]

199. Kaimoto, T.; Hatakeyama, Y.; Takahashi, K.; Imagawa, T.; Tominaga, M.; Ohta, T. Involvement of transient receptor potential $\mathrm{A}_{1}$ channel in algesic and analgesic actions of the organic compound limonene. Eur. J. Pain 2016, 20, 1155-1165. [CrossRef] [PubMed]

200. Estrada-Reyes, R.; Aguirre-Hernández, E.; García-Argáez, A.; Soto-Hernández, M.; Linares, E.; Bye, R.; Heinze, G.; Martínez-Vázquez, M. Comparative chemical composition of Agastache mexicana subsp. mexicana and A. mexicana subsp. xolocotziana. Biochem. Syst. Ecol. 2004, 32, 685-694. [CrossRef]

201. Sarrou, E.; Chatzopoulou, P.; Dimassi-Theriou, K.; Therios, I. Volatile constituents and antioxidant activity of peel, flowers and leaf oils of Citrus aurantium L. growing in Greece. Molecules 2013, 18, 10639-10647. [CrossRef] [PubMed]

202. González-Ramírez, A.E.; González-Trujano, M.E.; Pellicer, F.; López-Muñoz, F.J. Anti-nociceptive and anti-inflammatory activities of the Agastache mexicana extracts by using several experimental models in rodents. J. Ethnopharmacol. 2012, 142, 700-705. [PubMed]

203. González-Ramírez, A.E.; González-Trujano, M.E.; Orozco-Suárez, S.A.; Alvarado-Vásquez, N.; López-Muñoz, F.J. Nerol alleviates pathologic markers in the oxazolone-induced colitis model. Eur. J. Pharmacol. 2016, 776, 81-89. [CrossRef] [PubMed]

204. Gross, M.; Friedman, J.; Dudai, N.; Larkov, O.; Cohen, Y.; Bar, E.; Ravid, U.; Putievsky, E.; Lewinsohn, E. Biosynthesis of estragole and $\mathrm{t}$-anethole in bitter fennel (Foeniculum vulgare Mill. var. vulgare) chemotypes. Changes in SAM: Phenylpropene O-methyltransferase activities during development. Plant. Sci. 2002, 163, 1047-1053. [CrossRef]

205. Lucca, P.S.R.; Nóbrega, L.H.P.; Alves, L.F.A.; Cruz-Silva, C.T.A.; Pacheco, F.P. The insecticidal potential of Foeniculum vulgare Mill., Pimpinella anisum L. and Caryophillus aromaticus L. to control aphid on kale plants. Rev. Bras. Plantas Med. 2015, 17, 585-591. [CrossRef]

206. Aprotosoaie, A.C.; Costache, I.I.; Miron, A. Anethole and Its Role in Chronic Diseases. Adv. Exp. Med. Biol. 2016, 929, 247-267. [PubMed] 
207. Huang, Y.; Zhao, J.; Zhou, L.; Wang, J.; Gong, Y.; Chen, X.; Guo, Z.; Wang, Q.; Jiang, W. Antifungal activity of the essential oil of Illicium verum fruit and its main component trans-Anethole. Molecules 2010, 15, 7558-7569. [CrossRef] [PubMed]

208. Mohammed, M.J. Isolation and identification of anethole from Pimpinella anisum L. fruit oil: An antimicrobial study. J. Pharma. Res. 2009, 2, 915-919.

209. Freire, R.S.; Morais, S.M.; Catunda, F.E.A., Jr.; Pinheiro, D.C.S.N. Synthesis and antioxidant, anti-inflammatory and gastroprotector activities of anethole and related compounds. Bioorganic Med. Chem. 2005, 13, 4353-4358. [CrossRef] [PubMed]

210. Domiciano, T.P.; Dalalio, M.M.D.O.; Silva, E.L.; Ritter, A.M.; Estevão-Silva, C.F.; Ramos, F.S.; Caparroz-Assef, S.M.; Cuman, R.K.; Bersani-Amado, C.A. Inhibitory effect of anethole in nonimmune acute inflammation. Naunyn Schmiedebergs Arch. Pharmacol. 2013, 386, 331-338. [CrossRef] [PubMed]

211. Ghelardini, C.; Galeotti, N.; Mazzanti, G. Local anaesthetic activity of monoterpenes and phenylpropanes of essential oils. Planta Med. 2001, 67, 564-566. [CrossRef] [PubMed]

212. Ritter, A.M.V.; Ames, F.Q.; Otani, F.; de Oliveira, R.M.W.; Cuman, R.K.N.; Bersani-Amado, C.A. Effects of anethole in nociception experimental models. Evid. Based Complement. Altern. Med. 2014, 2014, 1-7. [CrossRef] [PubMed]

213. Ritter, A.M.V.; Domiciano, T.P.; Verri, W.A., Jr.; Zarpelon, A.C.; Da Silva, L.G.; Barbosa, C.P.; Natali, M.R.M.; Cuman, R.K.N.; Bersani-Amado, C.A. Antihypernociceptive activity of anethole in experimental inflammatory pain. Inflammopharmacology 2013, 21, 187-197. [CrossRef] [PubMed]

214. Chan, W.K.; Tan, L.T.; Chan, K.G.; Lee, L.H.; Goh, B.H. Nerolidol: A sesquiterpene alcohol with Multi-faceted pharmacological and biological activities. Molecules 2016, 21, 529. [CrossRef] [PubMed]

215. Koudou, J.; Abena, A.A.; Ngaissona, P.; Bessiére, J.M. Chemical composition and pharmacological activity of essential oil of Canarium schweinfurthii. Fitoterapia 2005, 76, 700-703. [CrossRef] [PubMed]

216. Klopell, F.C.; Lemos, M.; Sousa, J.P.B.; Comunello, E.; Maistro, E.L.; Bastos, J.K.; Andrade, S.F. Nerolidol, an antiulcer constituent from the essential oil of Baccharis dracunculifolia DC (Asteraceae). Z. Naturforsch. 2007, 62, 537-542. [CrossRef]

217. Fonsêca, D.V.; Salgado, P.R.; de Carvalho, F.L.; Salvadori, M.G.; Penha, A.R.; Leite, F.C.; Borges, C.J.; Piuvezam, M.R.; Pordeus, L.C.; Sousa, D.P.; et al. Nerolidol exhibits antinociceptive and anti-inflammatory activity: Involvement of the GABAergic system and proinflammatory cytokines. Fundam. Clin. Pharmacol. 2016, 30, 14-22. [CrossRef] [PubMed]

218. Morcia, C.; Tumino, G.; Ghizzoni, R.; Terzi, V.A. Carvone (Mentha spicata L.) oils. In Essential Oils in Food Preservation, Flavor and Safety; Academic Press: Cambridge, MA, USA, 2015; pp. 309-316.

219. Nogoceke, F.P.; Barcaro, I.M.; de Sousa, D.P.; Andreatini, R. Antimanic-like effects of (R)-(-)-carvone and (S)-(+)-carvone in mice. Neurosci. Lett. 2016, 21, 43-48. [CrossRef] [PubMed]

220. Salim, E.R.A.; Abu-Goukh, A.B.A.; Khalid, H.E.S.; El Hassan, G.M. Carvone content and chemical compositon in spearmint (Mentha spicata var. viridis L.) as affected by herb storage under ambient temperature. J. Food Nutr. Popul. Health 2016, 1, 1-7.

221. Gonçalves, J.C.; Oliveira, F.S.; Benedito, R.B.; de Sousa, D.P.; de Almeida, R.N.; de Araújo, D.A. Antinociceptive activity of (-)-carvone: Evidence of association with decreased peripheral nerve excitability. Biol. Pharm. Bull. 2008, 31, 1017-1020. [CrossRef] [PubMed]

222. Gonçalves, J.C.R.; Silveira, A.L.; de Souza, H.D.N.; Nery, A.A.; Prado, V.F.; Prado, M.A.M.; Ulrich, H.; Araújo, D.A.M. The monoterpene (-)-carvone: A novel agonist of TRPV1 Channels. Cytom. Part A 2013, 83, 212219. [CrossRef] [PubMed]

223. Melo, N.I.; Carvalho, C.E.; Fracarolli, L.; Cunha, W.R.; Veneziani, R.C.S.; Martins, C.H.G.; Crotti, A.E.M. Antimicrobial activity of the essential oil of Tetradenia riparia (Hochst.) Codd. (Lamiaceae) against cariogenic bacteria. Braz. J. Microbiol. 2015, 46, 519-525. [CrossRef] [PubMed]

224. Grajales-Conesa, J.; Ramírez, V.M.; Cruz-López, L.; Guillén, D.S. Effect of Citrus floral extracts on the foraging behavior of the stingless bee Scaptotrigona pectoralis (Dalla Torre). Rev. Bras. Entomol. 2012, 56, 76-80. [CrossRef]

225. Qamar, W.; Sultana, S. Farnesol ameliorates massive inflammation, oxidative stress and lung injury induced by intratracheal instillation of cigarette smoke extract in rats: An initial step in lung chemoprevention. Chem. Biol. Interact. 2008, 176, 79-87. [CrossRef] [PubMed] 
226. Oliveira Júnior, W.M.; Benedito, R.B.; Pereira, W.B.; Torres, P.A.; Ramos, C.A.F.; Costa, J.P.; Tomé, A.R.; de Sousa, D.P.; de Freitas, R.M.; Diniz, M.F.F.M.; et al. Farnesol: Antinociceptive effect and histopathological analysis of the striatum and hippocampus of mice. Fundam. Clin. Pharmacol. 2013, 27, 419-426. [CrossRef] [PubMed]

227. Jayaprakasha, G.K.; Jagan, M.R.L.; Sakariah, K.K. Volatile constituents from Cinnamomum zeylanicum fruit stalks and their antioxidant activities. J. Agric. Food Chem. 2003, 51, 4344-4348. [CrossRef] [PubMed]

228. Mockute, D.; Bernotiene, G.; Judzentiene, A. Chemical composition of essential oils of Origanum vulgare L. growing in Lithuania. Biologija 2004, 4, 44-49.

229. Menon, A.N.; Padmakumari, K.P.; Jayalekshmy, A. Essential oil composition of four major cultivars of black pepper (Piper nigrum L.)-IV. J. Essent. Oil Res. 2011, 14, 84-86. [CrossRef]

230. Gertsch, J.; Leonti, M.; Raduner, S.; Racz, I.; Chen, J.Z.; Xie, X.Q.; Altmann, K.H.; Karsak, M.; Zimmer, A. $\beta$-Caryophyllene is a dietary cannabinoid. Proc. Natl. Acad. Sci. USA 2008, 105, 9099-9104. [CrossRef] [PubMed]

231. Hendriks, H.; Malingre, T.; Battermann, S.; Boss, R. Mono- and sesquiterpene hydrocarbons of essential oil of Cannabis sativa. Phytochemistry 1975, 14, 814-815. [CrossRef]

232. Vijayalaxmi, A.; Vasudha, B.; Nazia, B.; Kowmudi, V.; Naveen, K.Y.; Yogesh, R. Anti-arthritc and anti-inflammatory actvity of $\beta$ caryophyllene against freund's complete adjuvant induced arthrits in wistar rats. J. Bone Rep. Recommend. 2015, 1, 1-10.

233. Martin, S.; Padilla, E.; Ocete, M.A.; Galvez, J.; Jiménez, J.; Zarzuelo, A. Anti-inflammatory activity of the essential oil of Bupleurum fruticescens. Planta Med. 1993, 59, 533-536. [CrossRef] [PubMed]

234. Katsuyama, S.; Mizoguchi, H.; Kuwahata, H.; Komatsu, T.; Nagaoka, K.; Nakamura, H.; Bagetta, G.; Sakurada, T.; Sakurada, S. Involvement of peripheral cannabinoid and opioid receptors in $\beta$-caryophyllene-induced antinociception. Eur. J. Pain 2013, 17, 664-675. [CrossRef] [PubMed]

235. Siqueira, B.P.J.; Menezes, C.T.; Silva, J.P.; de Sousa, D.P.; Batista, J.S. Antiulcer effect of epoxy-carvone. Braz. J. Pharmacog. 2012, 22, 144-149. [CrossRef]

236. Jirovetz, L.; Buchbauer, G.; Shafi, P.M.; Abraham, G.T. Analysis of the essential oil of the roots of the medicinal plant Kaempferia galanga L. (Zingiberaceae) from South India. Acta Pharm. Turc. 2001, 43, 107-110.

237. Iacobellis, N.S.; Lo Cantore, P.; Capasso, F.; Senatore, F. Antibacterial activity of Cuminum cyminum L. and Carum carvi L. essential oils. J. Agric. Food Chem. 2005, 53, 57-61. [CrossRef] [PubMed]

238. Klein, E.; Ohloff, G. Der stereochemische verlauf der alkalischen epoxydation von $\alpha, \beta$-ungesättigten carbonylverbindungen der cyclischen monoterpenreihe. Tetrahedron 1963, 19, 1091-1099. [CrossRef]

239. Arruda, T.A.; Antunes, R.M.P.; Catão, R.M.R.; Lima, E.O.; de Sousa, D.P.; Nunes, X.P.; Pereira, M.S.V.; Barbosa-Filho, J.M.; da Cunha, E.V.L. Preliminary study of the antimicrobial activity of Mentha x villosa Hudson essential oil, rotundifolone ant its analogues. Rev. Bras. Farmacogn. 2006, 16, 307-311. [CrossRef]

240. Almeida, R.N.; de Sousa, D.P.; Nóbrega, F.F.F.; Claudino, F.S.; Araújo, D.A.M.; Leite, J.R.; Mattei, R. Anticonvulsant effect of a natural compound $\alpha, \beta$-epoxy-carvone and its action on the nerve excitability. Neurosci. Lett. 2008, 443, 51-55. [CrossRef] [PubMed]

241. Da Rocha, M.L.; Oliveira, L.E.G.; Santos, C.C.M.P.; de Sousa, D.P.; de Almeida, R.N.; Araújo, D.A.M. Antinociceptive and anti-inflammatory effects of the monoterpene $\alpha, \beta$-epoxy-carvone in mice. J. Nat. Med. 2013, 63, 743-749. [CrossRef] [PubMed]

242. De Sousa, D.P.; de Sousa Oliveira, F.; de Almeida, R.N. Evaluation of the central activity of hydroxydihydrocarvone. Biol. Pharm. Bull. 2006, 29, 811-812. [CrossRef] [PubMed]

243. Oliveira, F.S.; de Sousa, D.P.; de Almeida, R.N. Antinociceptive effect of hydroxydihydrocarvone. Biol. Pharm. Bull. 2008, 31, 588-591. [CrossRef]

244. Peana, A.T.; D’Aquila, P.S.; Chessa, M.L.; Moretti, M.D.; Serra, G.; Pippia, P. (-)-Linalool produces antinociception in two experimental models of pain. Eur. J. Pharmacol. 2003, 460, 37-41. [CrossRef]

245. Peana, A.T.; de Montis, M.G.; Nieddu, E.; Spano, M.T.; D’Aquila, P.S.; Pippia, P. Profile of spinal and supra-spinal antinociception of (-)-linalool. Eur. J. Pharmacol. 2004, 485, 165-174. [CrossRef] [PubMed]

246. Peana, A.T.; Rubattu, P.; Piga, G.G.; Fumagalli, S.; Boatto, G.; Pippia, P.; de Montis, M.G. Involvement of adenosine A1 and A2A receptors in (-)-linalool-induced antinociception. Life Sci. 2006, 78, 2471-2474. [CrossRef] [PubMed] 
247. Batista, P.A.; Werner, M.F.; Oliveira, E.C.; Burgos, L.; Pereira, P.; Brum, L.F.; Story, G.M.; Santos, A.R. The antinociceptive effect of (-)-linalool in models of chronic inflammatory and neuropathic hypersensitivity in mice. J. Pain 2010, 11, 1222-1229. [CrossRef] [PubMed]

248. Letizia, C.S.; Cocchiara, J.; Lalko, J.; Api, A.M. Fragrance material review on linalool. Food Chem. Toxicol. 2003, 41, 943-964. [CrossRef]

(C) 2017 by the authors. Licensee MDPI, Basel, Switzerland. This article is an open access article distributed under the terms and conditions of the Creative Commons Attribution (CC BY) license (http://creativecommons.org/licenses/by/4.0/). 